\title{
Effects of E2HSA, a Long-Acting Glucagon Like Peptide-1 Receptor Agonist, on Glycemic Control and Beta Cell Function in Spontaneous Diabetic db/db Mice
}

\author{
Shaocong Hou, Caina Li, Yi Huan, Shuainan Liu, Quan Liu, Sujuan Sun, Qian Jiang, \\ Chunming Jia, and Zhufang Shen
}

State Key Laboratory of Bioactive Substances and Functions of Natural Medicines, Institute of Materia Medica, Chinese Academy of Medical Sciences and Peking Union Medical College, Beijing 100050, China

Correspondence should be addressed to Zhufang Shen; shenzhf@imm.ac.cn

Received 3 May 2015; Revised 2 July 2015; Accepted 28 July 2015

Academic Editor: Lucy Marzban

Copyright (C) 2015 Shaocong Hou et al. This is an open access article distributed under the Creative Commons Attribution License, which permits unrestricted use, distribution, and reproduction in any medium, provided the original work is properly cited.

\begin{abstract}
Glucagon like peptide-1 (GLP-1) receptor agonists such as exendin-4 have been widely used but their short half-life limits their therapeutic value. The recombinant protein, E2HSA, is a novel, long-acting GLP-1 receptor agonist generated by the fusion of exendin-4 with human serum albumin. In mouse pancreatic NIT-1 cells, E2HSA activated GLP-1 receptor with similar efficacy as exendin-4. After single-dose administration in ICR mice, E2HSA showed prolonged glucose lowering effects which lasted up to four days and extended inhibition on gastric emptying for at least 72 hours. Chronic E2HSA treatment in db/db mice significantly improved glucose tolerance, reduced elevated nonfasting and fasting plasma glucose levels, and also decreased HbAlc levels. E2HSA also increased insulin secretion and decreased body weight and appetite. Furthermore, immunofluorescence analysis showed that E2HSA increased $\beta$-cell area, improved islet morphology, and reduced $\beta$-cell apoptosis. In accordance with the promotion of $\beta$-cell function and survival, E2HSA upregulated genes such as Irs2, Pdx-1, Nkx6.1, and MafA and downregulated the expression levels of FoxO1 and proapoptotic Bcl-2 family proteins. In conclusion, with prolonged glucose lowering effects and promoting $\beta$-cell function and survival, the fusion protein, E2HSA, is a promising new therapeutic for once weekly treatment of type 2 diabetes.
\end{abstract}

\section{Introduction}

Type 2 diabetes mellitus (T2DM) has two major characteristics: reduced insulin sensitivity linked to obesity and impaired insulin secretion due to $\beta$-cell dysfunction [1]. $\beta$-cell dysfunction occurs when the demand for insulin finally overwhelms the capacity of the $\beta$-cell to respond [2], which results in severely reduced insulin secretion [3] and ultimately $\beta$-cell death [4]. Few available drugs can enhance $\beta$-cell viability and restore their ability to synthesize and secrete insulin without side effects such as hypoglycemia or weight gain. Glucagon like peptide-1 (GLP-1) represents such a therapeutic target to offer clinical benefits without the undesirable side effects mentioned above. GLP-1 is an incretin hormone secreted by enteroendocrine intestine $\mathrm{L}$ cells and plays an important role in glucose homeostasis and nutrient metabolism [5]. The action of GLP-1 is initiated by its binding to the GLP-1 receptor [6], which is expressed in islet $\alpha$-cells and $\beta$-cells and in other tissues, including the central and peripheral nervous systems and gastrointestinal tract. After binding to GLP1 receptor, GLP-1 stimulates insulin secretion in a glucose dependent manner, which means there is no or little risk of hypoglycemia [7]. Other effects include suppression of glucagon secretion, delayed gastric emptying, and increased satiety [6]. Through multiple signal transduction pathways, GLP-1 also promotes the proliferation and neogenesis of islet $\beta$-cells while at the same time reducing their apoptosis [8].

Native, endogenous GLP-1 is rapidly degraded by dipeptidyl peptidase-4 (DPP-4) [9], resulting in a half-life of only 12 minutes [10]. GLP-1 can be stabilized against DPP- 4 through substituting some amino acids, but elimination by the kidneys still renders it short-lived (half-life about 4-5 min) [11]. Therefore, more and more research is focusing on DPP4-resistant, long-acting GLP-1 receptor (GLP-1R) agonists. 
Exendin-4, a peptide originally isolated from lizard venom [12], shares a $53 \%$ amino acid sequence with mammalian GLP-1 and is resistant to DPP-4-mediated degradation [13]. Its synthetic form, exenatide, was the first GLP-1R agonist available on the market. Exenatide has a relatively longer circulating half-life of 90-216 minutes (average 2.4 h) and thus needs to be injected twice daily [14]. The second available GLP-1R agonist, liraglutide, extends its half-life by noncovalently interacting with albumin, but due to clearance by the kidney [15] once daily administration is still necessary [16].

Although exenatide and liraglutide have beneficial effects on blood glucose control, the requirement for once or twice daily injections limits their clinical use. Because the kidney generally filters out molecules below $60 \mathrm{kDa}$ [17] and albumin $(\sim 67 \mathrm{kDa})$ has a much longer half-life in humans [18] a fused exendin-4-albumin protein should exhibit a prolonged circulating half-life. E2HSA, the recombinant protein we report here, is the product of such a strategy. E2HSA is a recombinant exendin-4-human serum albumin (HSA) fusion protein which retains the GLP-1 receptor binding activity of exendin-4 and as such is expected to exert glucose lowering effects with a prolonged duration. Thus, the aims of the present study were to evaluate its acting time and its antidiabetic efficacy in vivo. The effect on $\beta$-cell function and survival after chronic treatment was also assessed to elucidate possible mechanisms.

\section{Materials and Methods}

2.1. Materials. E2HSA (Patent no. CN101525386A) was provided by Zhejiang Huayang Pharma Inc. (China) as freezedried powder. Exendin-4 (exenatide) was a product of Eli Lilly and Company (USA). Lipofectamine 2000 was obtained from Invitrogen (USA). Rat anti-insulin antibody was purchased from R\&D Inc. (USA). Rabbit anti-glucagon antibody, rabbit anti-FoxO1 antibody, rabbit anti-phospho-FoxO1 antibody, rabbit anti-BAD antibody, rabbit anti-phospho-BAD antibody, rabbit anti-Bim antibody, rabbit anti-Bcl-2 antibody, rabbit anti-Bcl-XL antibody, and rabbit anti-PhosphoErk1/2 antibody were all purchased from Cell Signaling Technology Inc. (USA). The in situ cell death detection kit was a product of Roche Inc. (USA).

2.2. Animals. Male ICR mice weighing 20-22g were purchased from Vital River Laboratory Animal Technology Co. Ltd. (Beijing, China) and housed five per cage with access to standard chow (Research Diets, Inc., Beijing, China) and water at constant room temperature $\left(22 \pm 3^{\circ} \mathrm{C}\right)$ in a $12 \mathrm{~h}$ light/dark cycle.

Female $\mathrm{db} / \mathrm{db}$ (BKS.Cg- $m+/+$ Lepr $^{\mathrm{db}} / \mathrm{J}$ ) mice aged 6-7 weeks were purchased from Changzhou Cavens Laboratory Animal Co. Ltd. (Changzhou, China). db/db mice were housed four or three per cage at constant room temperature $\left(22 \pm 3^{\circ} \mathrm{C}\right)$ in a $12 \mathrm{~h}$ light/dark cycle and fed ad libitum with a special diet (protein content is higher; other ingredients are the same as standard diet) supplied by Changzhou Cavens Laboratory Animal Co. Ltd. (Changzhou, China).
Age-matched heterozygotes $\mathrm{db} / \mathrm{m}$ mice were used as control animals. $\mathrm{db} / \mathrm{m}$ mice were housed five per cage under the same conditions and fed ad libitum with standard diet (Research Diets, Inc., Beijing, China).

All animals were handled in accordance with the standards for laboratory animals established by China (GB149252001), and all efforts were made to minimize suffering.

2.3. GLP-1 Receptor Activation In Vitro. Mouse pancreatic $\beta$-cell line NIT-1 was purchased from ATCC. Cells were cultured with DMEM/F12 media containing 10\% (v/v) fetal bovine serum and $100 \mathrm{mg} / \mathrm{L}$ penicillin-streptomycin and incubated at $37^{\circ} \mathrm{C}$ in $5 \% \mathrm{CO}_{2}$ atmosphere. The plasmid Peak12 RIP-CRE 6x Luciferase was constructed as described [19]. Briefly, six copies of a GLP-1 specific cAMPresponse element-like sequence of rat insulin promoter (RIPCRE) were inserted in Peak12 Sx Syn E-Luciferase plasmid upstream of the Luciferase reporter gene. After the plasmid was transfected into NIT-1 cells, Luciferase expression can be specifically and dose-dependently induced by GLP-1 receptor agonists via GLP-1 receptor activation.

Cells were seeded in 6-well plates and transiently transfected with Peak12 RIP-CRE 6x Luciferase plasmid using Lipofectamine 2000 following the manufacture's protocols. Twenty hours later, the cells were transferred to 96-well plates and treated with indicated concentrations of E2HSA and exendin- 4 for 24 hours. Cells were harvested and Luciferase expression was measured by the chemiluminescence assay. Data obtained were plotted as 4-parameter logistic curve, and activation fold and $\mathrm{EC}_{50}$ were calculated:

$$
\begin{aligned}
& \text { Activation fold } \\
& =\frac{\text { Chemiluminiscene in treated group }}{\text { Chemiluminiscene in control group }} .
\end{aligned}
$$

\subsection{Single Dose of E2HSA in Normal ICR Mice}

2.4.1. Oral Glucose Tolerance Test (OGTT). Normal ICR mice were divided randomly into five groups ( $n=10 /$ group): normal saline treated group (Nor.), different dosages of E2HSA treated groups ( $1 \mathrm{mg} / \mathrm{kg}, 3 \mathrm{mg} / \mathrm{kg}$, and $9 \mathrm{mg} / \mathrm{kg}$ resp.), and exendin-4 $(2 \mu \mathrm{g} / \mathrm{kg})$ treated group. The doses of E2HSA were chosen based on its molecular weight, doses of similar large agonists of GLP-1R utilizing $\operatorname{HSA}[15,20,21]$, and preliminary experiments in our lab. Exendin-4 was used at the dose converted from the human equivalent dose (based on body surface area) [22] in the clinic (10 $\mu$ g, twice daily) to serve as a positive control. All mice were fasted overnight with water ad libitum before the experiment. E2HSA and exendin4 were injected subcutaneously at doses described above and twenty minutes later all mice were orally challenged with glucose $(2 \mathrm{~g} / \mathrm{kg})$. Blood samples were taken from the tail tip before E2HSA and exendin-4 injection (as 0 minute) and at 30,60 , and 120 minutes after glucose loading. To observe the lasting time of exendin-4, a second OGTT was carried out at about $4 \mathrm{~h}$ after the injection. On the 2 nd day to 7 th day of the injection, blood was sampled only at fasted state (as 0 minute) and at $30 \mathrm{~min}$ after glucose loading. 
2.4.2. Nonfasting Blood Glucose and Food Intake. Normal ICR mice were grouped, fasted, and treated as above. After injection, all mice were fed with normal chow. Blood glucose levels were then determined $1 \mathrm{~h}$ and $5 \mathrm{~h}$ later and daily on the 2nd day to 6th day. Food intake was recorded during the experiment, measured by weighing and calculating the differences of chow weight per cage between indicated time points. The sum was divided by sample size and then expressed as food intake per mouse within the indicated time period.

2.4.3. Gastric Emptying Test. The experiment was staggered into four cohorts. Twenty mice in the first cohort were divided randomly into 2 groups $(n=10 /$ group): normal saline treated group and exendin- $4(2 \mu \mathrm{g} / \mathrm{kg})$ treated group. The second cohort consisted of fifty mice which were divided randomly into five groups as described in Section 2.4.1. The third and fourth cohorts contained forty mice each and were both divided randomly into four groups as described in Section 2.4 .1 but with subtraction of the exendin- 4 treated group.

All mice were fasted overnight with water ad libitum. On the experiment day, mice were injected subcutaneously with E2HSA, exendin-4, or normal saline, respectively, at doses described above. Ink was orally given to different groups at $0.5 \mathrm{~h}$ (1st cohort), $5 \mathrm{~h}$ (2nd cohort), $24 \mathrm{~h}$ (3rd cohort), and $72 \mathrm{~h}$ (4th cohort) after the injection, respectively. Fifteen minutes later, mice were sacrificed and the small intestine was isolated; the total length of small intestine and the distance of ink delivered were measured. Gastric emptying rate was then calculated as the ratio of ink delivery distance/total length of small intestine.

\subsection{Chronic Treatment of E2HSA in Spontaneous \\ Type 2 Diabetes db/db Mice}

2.5.1. Animals Handling and Treatment. $\mathrm{db} / \mathrm{db}$ mice were randomly divided into five groups: the vehicle (normal saline) treated group (Con.), three different dosages of E2HSA $(1 \mathrm{mg} / \mathrm{kg}, 3 \mathrm{mg} / \mathrm{kg}$, and $9 \mathrm{mg} / \mathrm{kg}$, resp.) treated groups, and exendin-4 $(2 \mu \mathrm{g} / \mathrm{kg})$ treated group. Ten age- and gendermatched $\mathrm{db} / \mathrm{m}$ mice served as normal controls (Nor.). E2HSA was injected subcutaneously once daily at doses described above and exendin- 4 was given twice daily at the dose of $2 \mu \mathrm{g} / \mathrm{kg}$. Both Con. and Nor. groups were injected with vehicle (normal saline) once daily. The treatment lasted for 43 days (about 6 weeks). At the end of study, all mice were decapitated and plasma samples were stored at $-80^{\circ} \mathrm{C}$ for subsequent biochemical analysis. The pancreatic tissues were immediately removed and weighed. Samples were fixed for immunofluorescence analysis or stored at $-80^{\circ} \mathrm{C}$ for subsequent preparation of total RNA and proteins.

2.5.2. OGTT, IVGTT, and Plasma Biochemical Analysis. OGTTs were carried out weekly except for the 4th week. Fasting plasma glucose (FPG) levels and nonfasting plasma glucose (non-FPG) levels were measured every week, and, additionally, non-FPG levels at 1 hour and 5 hours after treatment on the first day were also measured. Nonfasting blood samples from 37th day were collected and HbAlc levels were evaluated using commercial kits (Beijing HOMA Biologicals, China). Fasting plasma insulin levels on the 20th day and 34th day were measured by ELISA (American Laboratories Product Co., USA.). For IVGTT, on day 40, after overnight food deprivation, $250 \mathrm{mg} / \mathrm{kg}$ glucose was injected through tail vein and blood samples were taken $2 \mathrm{~min}, 5 \mathrm{~min}$, and $8 \mathrm{~min}$ after the intravenous glucose challenge; plasma insulin levels from each time point were analyzed. After the mice were sacrificed on 43rd day, blood samples were collected to test plasma glucagon levels using ELISA kit from R\&D Systems, Inc., USA. Plasma triglyceride and total cholesterol levels were measured at the 1st week, 3rd week, and 5th week using commercial kits (BioSino Bio-technology and Science, Inc., China). Plasma FFA levels were evaluated at the 2nd week and 4th week also with commercial kits (Sekisui Medical, Tokyo, Japan). Food and water intake and body weights were monitored every day; the food and water data were then normalized to intake per mouse per week.

2.6. Immunofluorescence. After sacrifice, pancreases were dissected and fixed in aqueous Bouin's solution and then embedded in paraffin. Serial $5 \mu \mathrm{m}$ paraffin-embedded sections were mounted on slides. Two sets of stains were prepared. In one case, sections were dewaxed using xylene, rehydrated through serial dilutions of ethyl alcohol, and subjected to antigen retrieval using Tris-EDTA ( $\mathrm{pH}$ 9.0). Sections were incubated overnight with a cocktail of two primary antibodies: rabbit anti-glucagon antibody $(1: 25)$ and rat anti-insulin antibody $(1: 45)$. The antigens were visualized using a cocktail of Fluorescein conjugated secondary antibody and Rhodamine conjugated secondary antibody (ZSGB-Bio, Inc., China). In another set, sections were labeled by TUNEL according to manufacturer's instructions followed by staining with rat anti-insulin antibody. All images were acquired through a fluorescence microscope equipped with a charge-coupled device camera (Olympus Inc. JPN). The ratio of insulin positive beta-cells to total islet area and the ratio of TUNEL positive $\beta$-cell to total insulin positive cells were calculated from digitized images captured under $20 \mathrm{x}$ objective using ImageJ software.

2.7. Western Blot. Total protein was extracted from frozen pancreas (the tail of pancreas) using RIPA lysis buffer (Applygen Technologies Inc., China) supplied with a protease and phosphatase inhibitor cocktail (Cell Signaling Technologies, USA). Protein was quantitated by BCA assay and denatured. Equal amounts of protein were resolved and separated electrophoretically by SDS-PAGE before transfer to polyvinylidene difluoride membranes. Membranes were then blocked for 1 hour with 5\% nonfat milk in Tris-buffered saline $(0.1 \%$ Tween-20) and different blots were incubated overnight with indicated primary antibodies (all in 1:500 dilution) at $4^{\circ} \mathrm{C}$. After washing, blots were incubated at RT with horseradish peroxidase-conjugated secondary antibody (ZSGB-Bio, Inc., China). Proteins were visualized using 
an enhanced chemiluminescence detection system (ChemiScope 2850, Clinx Science Instruments, China) and band densities were analyzed by ImageJ software. The expression of $\beta$-actin protein served as internal standard. Data were expressed as fold expression relative to expression in vehicle treated Con. group.

2.8. Quantitative Real-Time PCR. Total RNA was extracted from frozen pancreas (the tail of pancreas) using TRIzol reagent (Invitrogen, USA) and further purified. Concentrations and $260 / 280 \mathrm{~nm}$ or $260 / 230 \mathrm{~nm}$ ratios of purified total RNA were analyzed by a Biodropsis BD-2000 spectrophotometer (OSTD Beijing Co. Ltd., China). cDNA was then synthesized using VigoScript First Strand cDNA Synthesis Kit (Vigorous Biotechnology Beijing Co., Ltd., China) and subjected to quantitative real-time PCR utilizing 7900 RealTime PCR System (Applied Biosystems, USA). cDNA was amplified with SYBR Green Master Mix (Takara, China) using the following protocol: 1 cycle at $95^{\circ} \mathrm{C}$ for $30 \mathrm{~s}$ followed by 40 cycles at $95^{\circ} \mathrm{C}$ for $5 \mathrm{~s}$ and $60^{\circ} \mathrm{C}$ for $31 \mathrm{~s}$. Specific PCR primers were designed by Primer-BLAST and synthesized by Invitrogen (Beijing, China). Data were calculated using deltadelta $\mathrm{Ct}\left({ }^{\Delta \Delta} \mathrm{Ct}\right)$ method and expressed as fold expression relative to expression in vehicle treated Con. group. The level of $\beta$-actin served as an internal standard.

Primer sequences used were as follows:

ATGAACAGTGAGGAGCAGTAC' and ACGGGTCCTCTTGTTTTCCTC for Pdx-1.

CACAATTCCAAGCGCCACAA and CATCACCTCCTCCCAGGGTA for Irs2.

CCATCAGCAAGCAGGAAGGTTA and GCTTGACAAAAGCCTGGGTG for Ins2.

AGGCAAAGAGGGACATGCGGGA and TGCTTCAGCTCCTCT GCGGC for Igfl.

CCGCGCCTCCCAACCTTGTT and TTCTCCA CCCCCGCGGGAAA for Nkx6.1.

GCGCCTCAGGAAAAGCGGTG and AGCGCCTCGGGGTTCAGGTG for MafA.

2.9. Statistical Analysis. All values are presented as mean \pm S.E.M. Data were analyzed by ANOVA followed by Bonferroni's correction and Student's $t$-test (two-tailed test). Analysis was performed using Excel (Microsoft, Redmond, WA) or Prism (GraphPad Software Inc., San Diego, CA). The $P$ value less than 0.05 was considered to be statistically significant.

\section{Results}

3.1. GLP-1 Receptor Activation in NIT-1 Cells. E2HSA produced a dose-dependent activation of the GLP-1 receptor in NIT-1 cells with concentrations ranging from $0.1 \mathrm{nM}$ to $1000 \mathrm{nM}$. Compared to exendin-4, E2SHA showed a similar max GLP-1R activation fold (3.3-fold) but different $\mathrm{EC}_{50}(28.2 \mathrm{nM}$ for E2HSA versus $0.215 \mathrm{nM}$ for exendin-4) (Figure 1). The results showed that the recombinant fusion

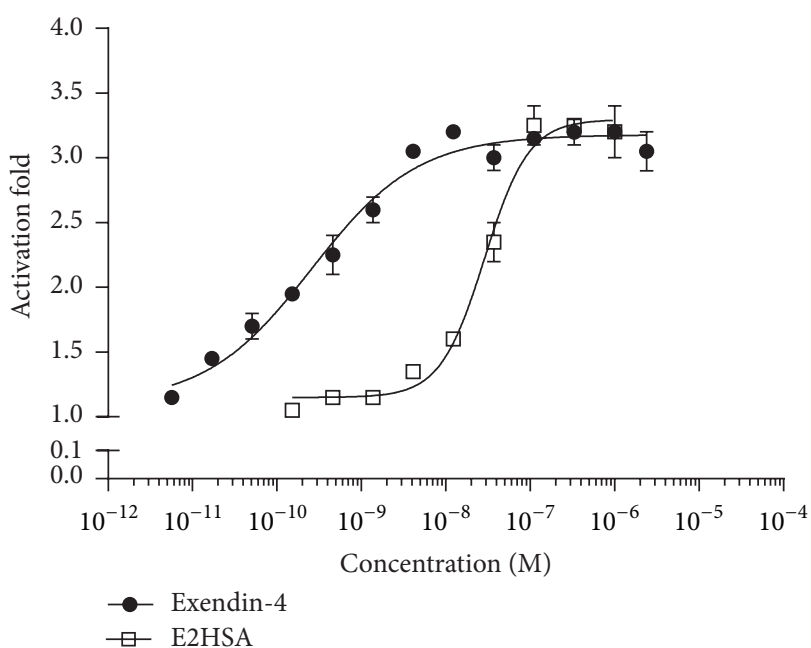

FIGURE 1: E2HSA exhibits GLP-1 receptor activating efficacy in NIT1 cells. NIT-1 cells transiently transfected with Peak12 RIP-CRE 6x Luciferase reporter gene plasmid were treated with indicated concentrations of E2HSA and exendin- 4 for 24 hours. Luciferase expression in cell lysates was measured by chemiluminescence. Data obtained were used to calculate the activation fold at different concentrations. Values are expressed as means \pm S.E.M and are representative of data from two independent experiments, each performed in quadruplicate.

protein of exendin-4 and human serum albumin (HSA) possessed the same efficacy as exendin- 4 to recognize and activate GLP-1 receptor but with lower potency perhaps due to steric hindrance of the HSA.

3.2. Extended Glucose Lowering and Gastric Emptying Effects after a Single Dose of E2HSA in Normal ICR Mice. In normal ICR mice, a single administration of E2HSA dosedependently reduced glucose levels and area under curves (AUC) after oral glucose challenge at 20 minutes and 4 hours after administration on the first day. On the other hand, exendin-4 (Ex-4) ceased to suppress elevated glucose levels at 4 hours after administration (Figures 2(a)-2(d)). Furthermore, from the second day to the fifth day, E2HSA still significantly suppressed the elevated blood glucose levels at 30 minutes after oral glucose challenge. Eventually, the effect of E2HSA on blood glucose levels diminished on the last two days (Figure 2(e)). Thus, the glucose lowering effect of E2HSA could last at least 4 days and in a dose-dependent manner. We also observed such changes in nonfasting blood glucose levels after a single administration of E2HSA (Figure 3(a)). As expected, E2HSA displayed an extended, dose-dependent blood glucose lowering effect that lasted to the 4th day, though the effect of $1 \mathrm{mg} / \mathrm{kg}$ E2HSA was not significant on the 3rd and 4th days. Notably, exendin-4 lost its effect on the second day.

To validate the effect of E2HSA on gastric emptying, we measured the delivered distance of orally administered ink in the small intestine and the total length of the small intestine to calculate the gastric emptying rate (Figure $3(\mathrm{~b})$ ). The rates in E2HSA-treated groups were significantly lower than those in 


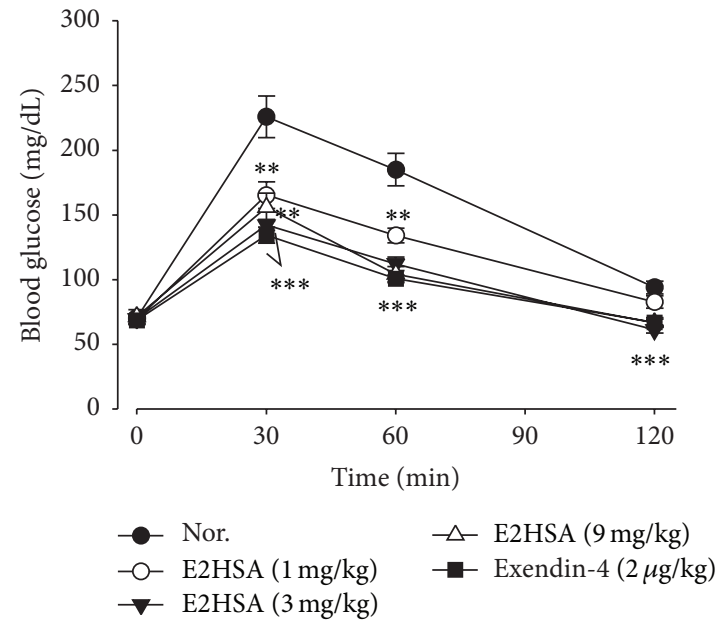

(a)

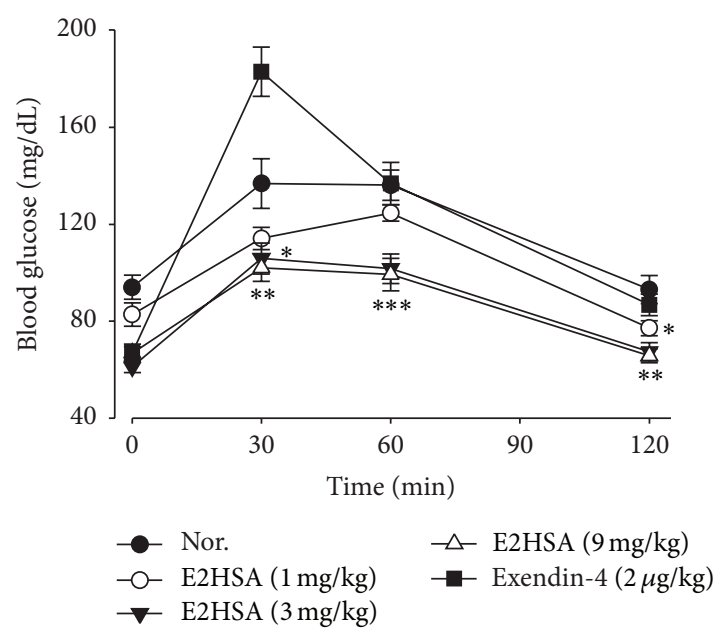

(c)

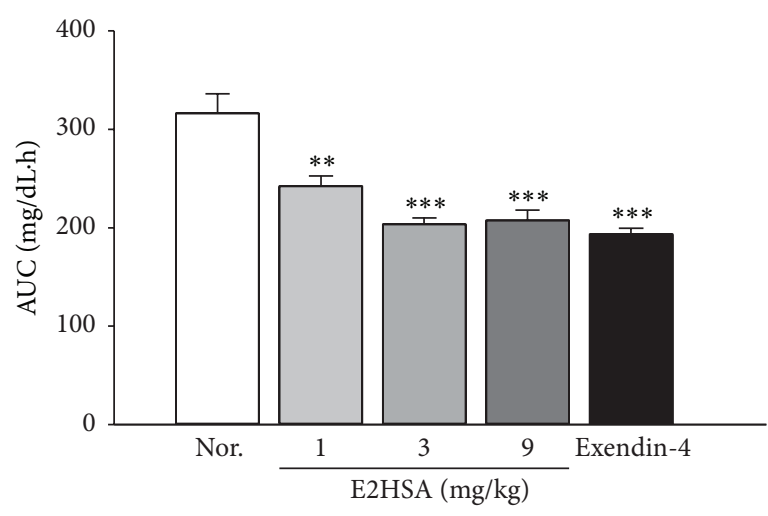

(b)

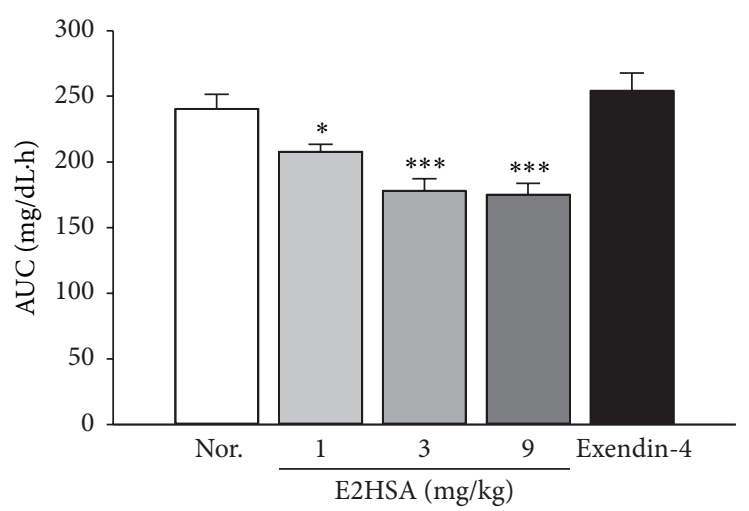

(d)

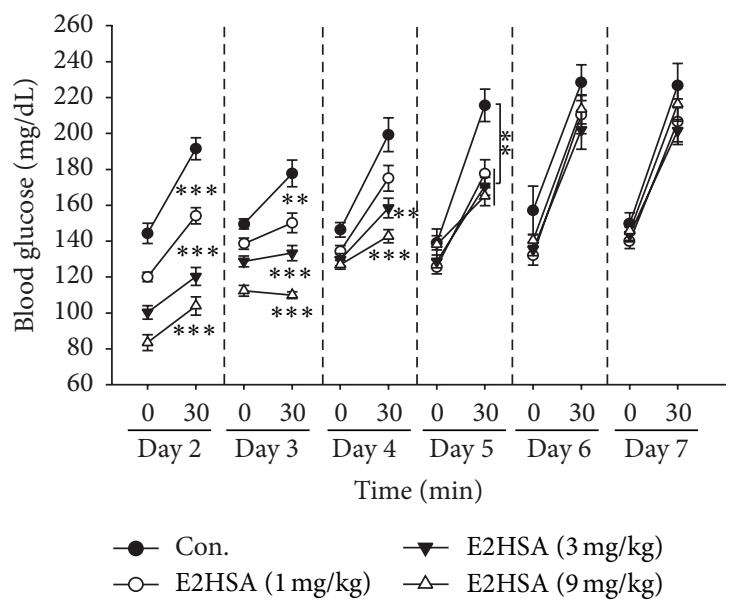

(e)

FIGURE 2: Long-acting, glucose lowering effect of E2HSA following oral glucose challenge in normal ICR mice administered a single dose. ((a)-(b)) Curves of blood glucose and AUC after first oral glucose loading performed at 20 minutes after administration of E2HSA. ((c)-(d)) Curves of blood glucose and AUC after second oral glucose challenge carried out at 4 hours after administration. (e) Blood glucose levels at fasting state and 30 minutes after oral glucose challenge on the 2 nd day to 7 th day after administration. Nor., normal ICR mice administered normal saline. Exendin-4, exendin-4 treated group. Data are expressed as mean \pm S.E.M $(n=10) .{ }^{*} P<0.05,{ }^{* *} P<0.01$, and ${ }^{* * *} P<0.001$ versus Nor. 


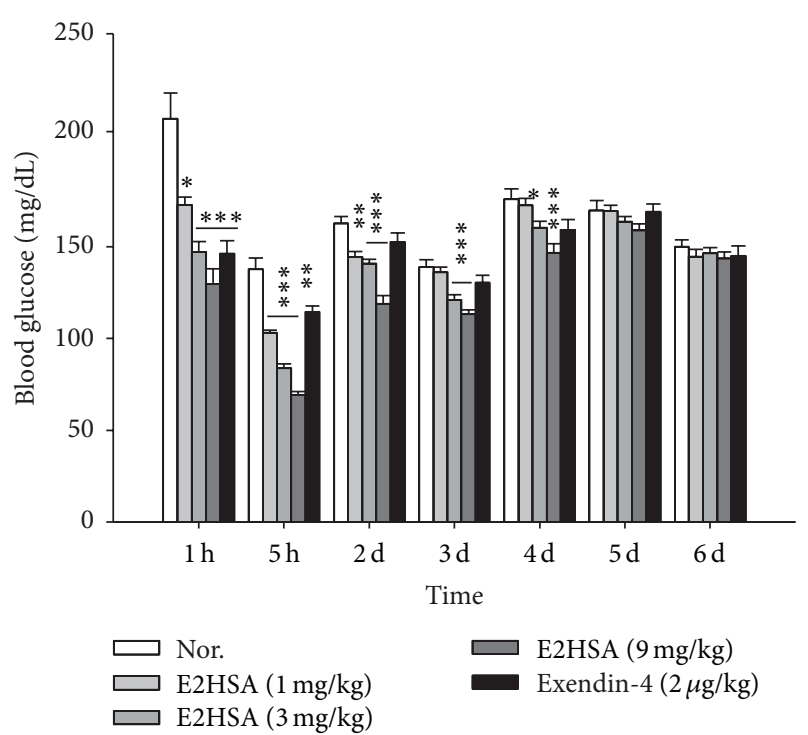

(a)

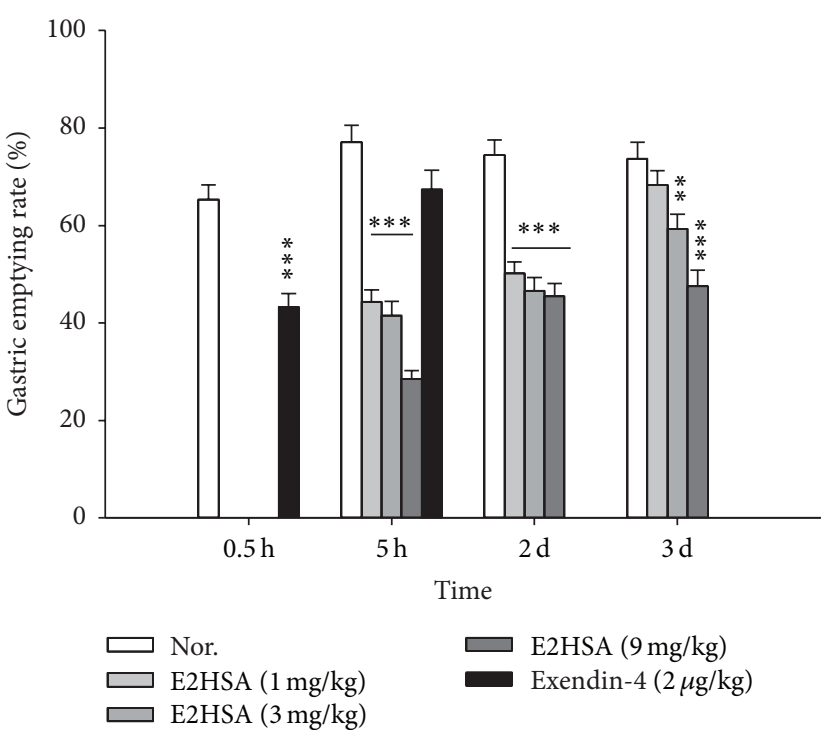

(b)

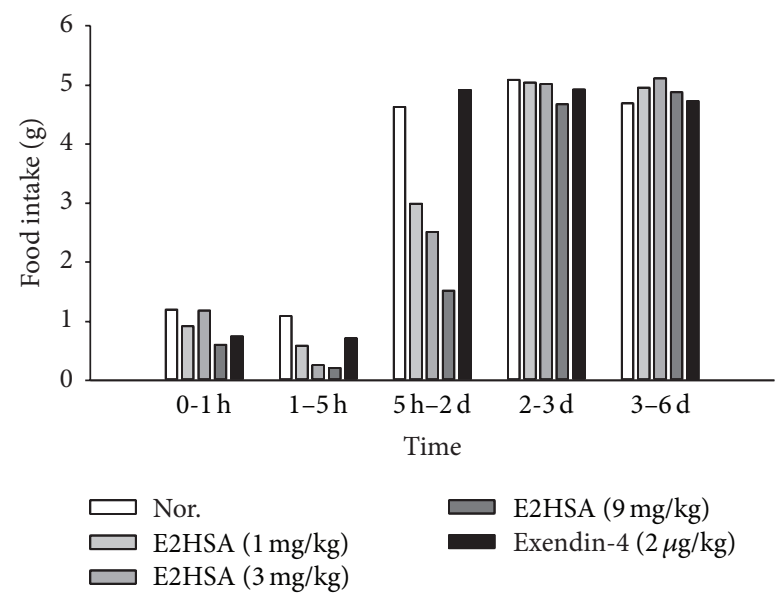

(c)

FIGURE 3: Long-acting effects of E2HSA on nonfasting blood glucose levels (a), gastric emptying (b), and food intake per mouse (c) in normal ICR mice injected with a single dose subcutaneously. Food intake was measured per cage and expressed as food intake per mouse within the indicated time period. Nor., normal ICR mice administered saline. Data are expressed as mean \pm S.E.M $(n=10) .{ }^{*} P<0.05$, ${ }^{* *} P<0.01$, and ${ }^{* * *} P<0.001$ versus Nor.

saline-treated normal groups, suggesting that gastric emptying and small intestine peristalsis were inhibited. This effect was also dose-dependent and could last to the 3rd day after only a single administration of E2HSA. On the other hand, we could not observe any inhibition on gastric emptying 5 hours after administration in the exendin-4-treated groups. Consistent with its inhibition of gastric emptying, food intake in E2HSA-treated ICR mice also showed a reduction up to the 2 nd day after a single administration (Figure 3(c)). One hour after administration, the effects of E2HSA and exendin4 on food intake were comparable (dropped by $23.3 \%$ and $50 \%$ for $1 \mathrm{mg} / \mathrm{kg}$ and $9 \mathrm{mg} / \mathrm{kg}$ E2HSA, respectively, and by $38 \%$ for exendin-4). At 5 hours after administration, the reduction in food intake was $45.9 \%, 76.1 \%$, and $80.7 \%$ for $1 \mathrm{mg} / \mathrm{kg}, 3 \mathrm{mg} / \mathrm{kg}$, and $9 \mathrm{mg} / \mathrm{kg}$ E2HSA, respectively, while the reduction with exendin- 4 administration remained at $34.9 \%$.
On the second day, exendin-4 no longer had any effect on food intake, but E2HSA could still decrease food intake by $35.4 \%, 45.7 \%$, and $67.1 \%$, respectively. The effect of E2HSA on food intake became subtle on the 3rd day and disappeared thereafter.

3.3. Chronic Treatment of E2HSA Improved Glycemic Control in $\mathrm{db} / \mathrm{db}$ Mice. During 43 days of treatment, $1 \mathrm{mg} / \mathrm{kg}$, $3 \mathrm{mg} / \mathrm{kg}$, and $9 \mathrm{mg} / \mathrm{kg}$ doses of E2HSA all significantly decreased nonfasting and fasting blood glucose levels in a dose-dependent manner, and such effects were maintained throughout the entire treatment (Figures 4(a)-4(b)). Exendin-4 showed a comparable reduction in nonfasting and fasting blood glucose levels for the first two or three weeks, but then its efficacy became variable and the glycemic 


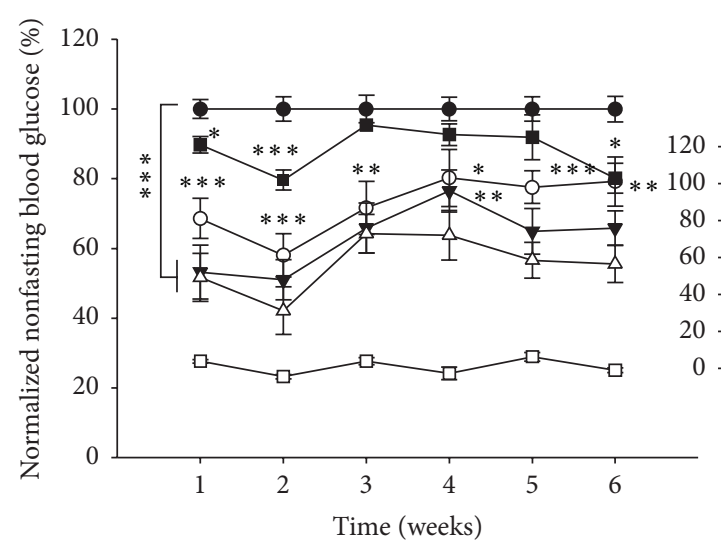

- Con.
$-\mathrm{O}$ E2HSA (1 mg/kg)

$\neg$ E2HSA $(3 \mathrm{mg} / \mathrm{kg})$

$\triangle \quad$ E2HSA $(9 \mathrm{mg} / \mathrm{kg})$

- Exendin-4 $(2 \mu \mathrm{g} / \mathrm{kg})$

(a)

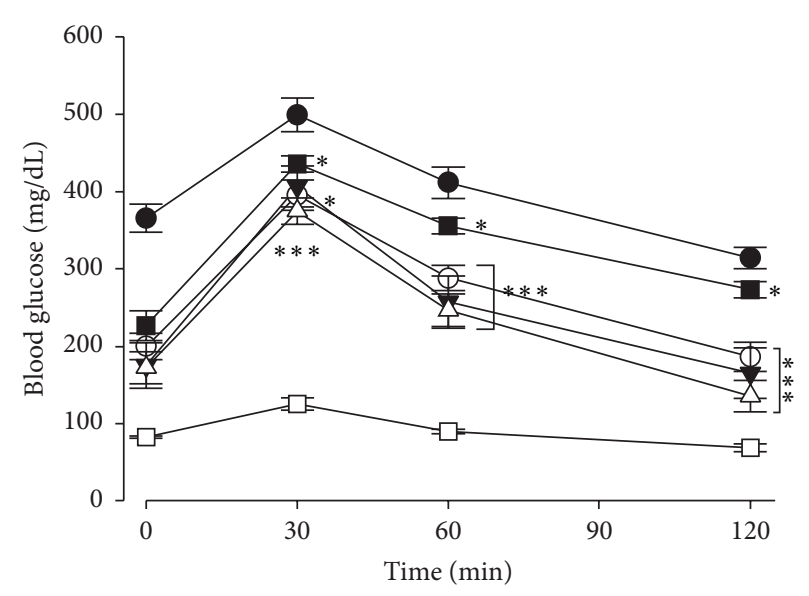

$\begin{array}{ll}-- \text { Con. } & -\checkmark \text { E2HSA }(9 \mathrm{mg} / \mathrm{kg}) \\ -\bigcirc-\text { E2HSA }(1 \mathrm{mg} / \mathrm{kg}) & -\square \text { Exendin }-4(2 \mu \mathrm{g} / \mathrm{kg}) \\ \rightarrow-\text { E2HSA }(3 \mathrm{mg} / \mathrm{kg}) & -\square-\text { Nor. }\end{array}$

(c)

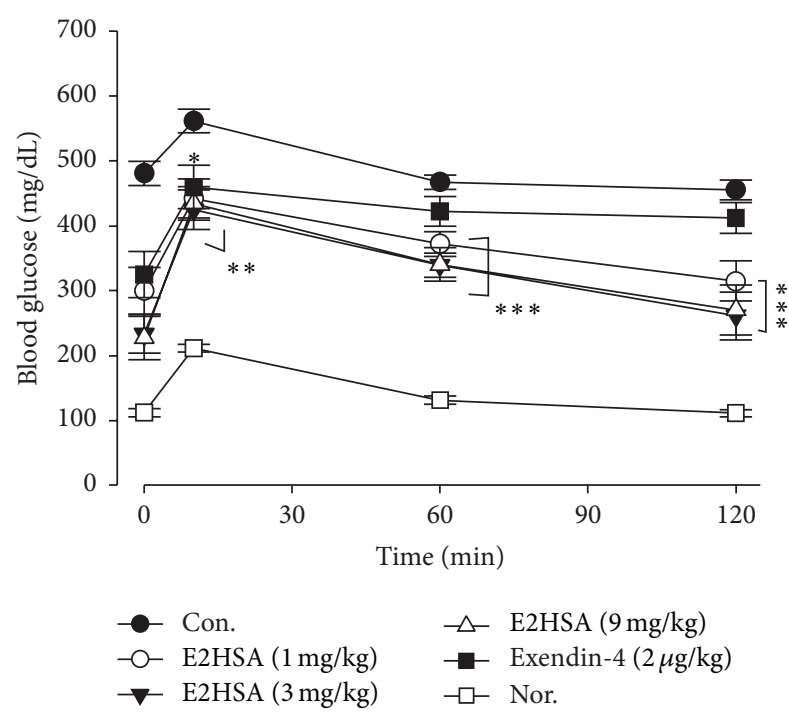

(e)

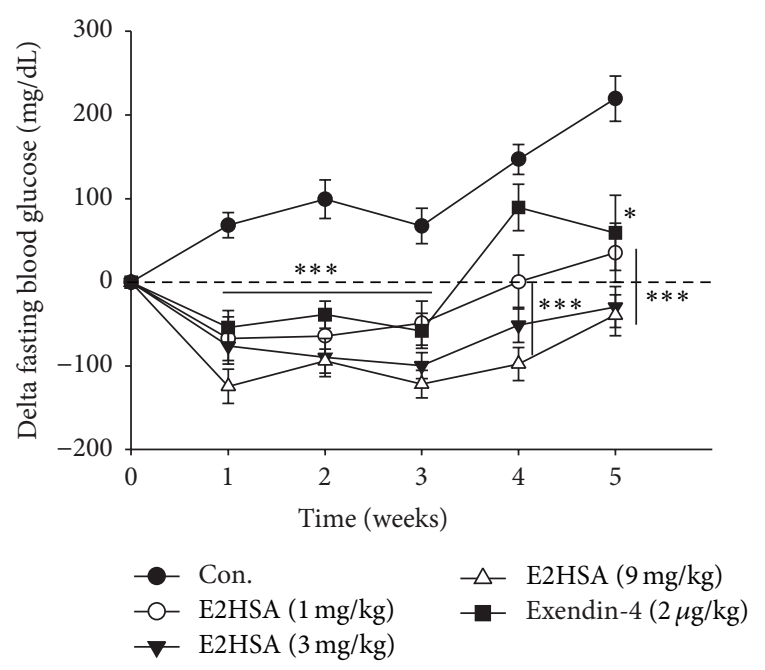

(b)

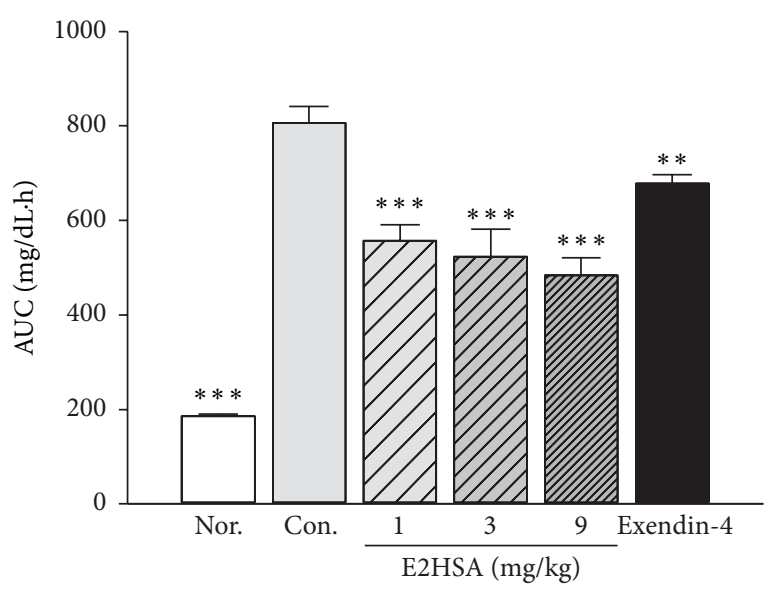

(d)

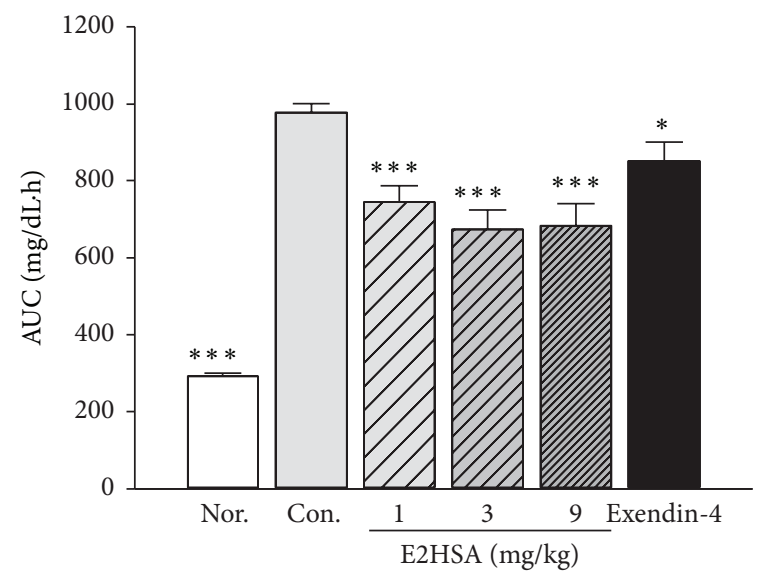

Figure 4: Continued. 


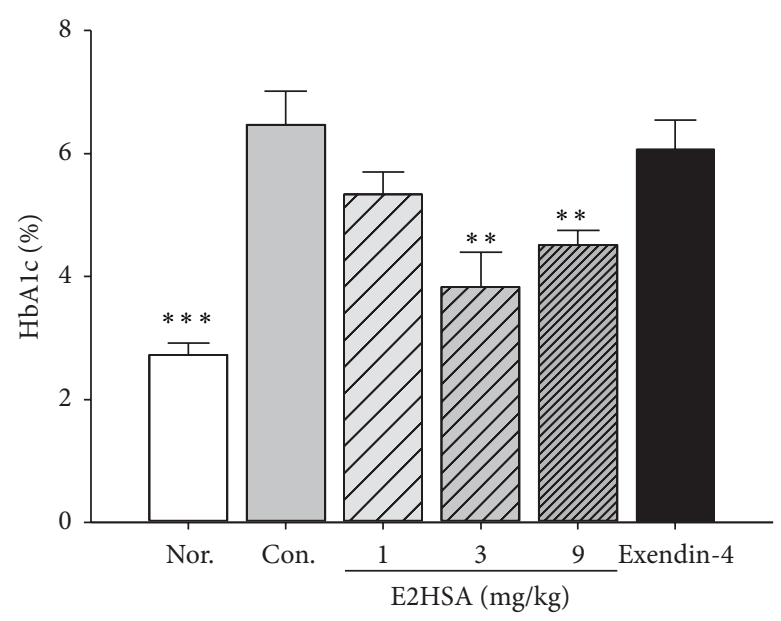

(g)

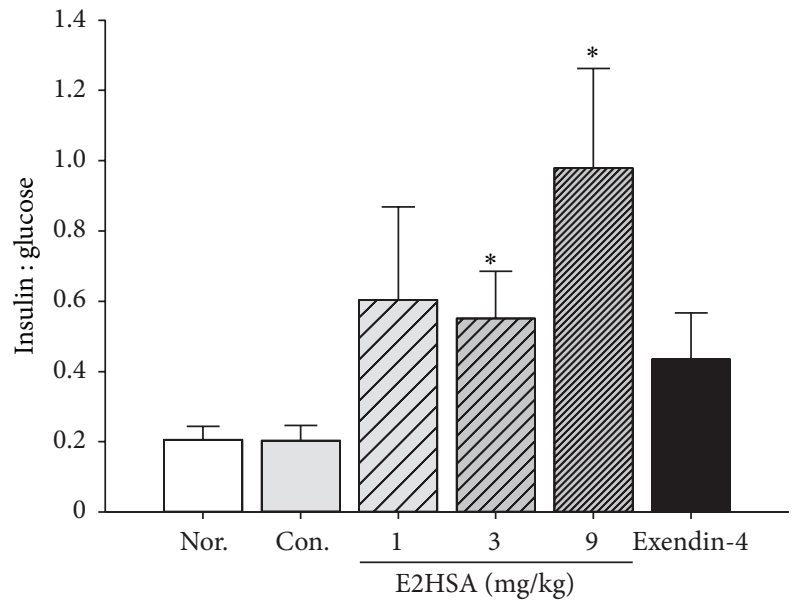

(h)

FIGURE 4: Chronic treatment with E2HSA improved glycemic control in spontaneous type 2 diabetes db/db mice. (a) Nonfasting blood glucose levels normalized by setting blood glucose levels in the control group to $100 \%$. The mini figure shows the nonfasting blood glucose levels at 1 hour and 5 hours after E2HSA and exendin-4 administration on the first day. (b) Changes in fasting blood glucose levels relative to levels before E2HSA treatment. ((c) and (d)) Blood glucose curves and AUC of OGTT on the 2nd week. ((e) and (f)) Blood glucose curves and AUC of OGTT on the 5th week. (g) HbAlc levels on the 37th day. (h) Insulin/glucose ratios at 10 minutes following glucose challenge on the 5 th week. Nor., $\mathrm{db} / \mathrm{m}$ mice administered normal saline. Con., $\mathrm{db} / \mathrm{db}$ mice administered normal saline. Data are expressed as mean \pm S.E.M $(n=10-11) .{ }^{*} P<0.05,{ }^{* *} P<0.01$, and ${ }^{* * *} P<0.001$ versus Con.

control in that group was worse than E2HSA-treated groups in the following weeks. OGTTs were performed on the 1st, 2nd, 3rd, and 5th weeks of E2HSA administration (the data from 1st and 3rd week are not shown). The results of the 2nd and 5th weeks are shown in Figures 4(c)-4(f). Glucose tolerance in E2HSA-treated $\mathrm{db} / \mathrm{db}$ mice was significantly improved at all weeks tested. By the 2nd week, blood glucose levels following glucose challenge decreased significantly; the AUC in three doses of E2HSA-treated groups dropped $31.5 \%, 35.2 \%$, and $40.1 \%$, compared to the control group (Figures 4(c)-4(d)). By the 5th week, glucose levels after glucose challenge were still greatly reduced by all doses of E2HSA, with $23.8 \%, 31.0 \%$, and $30.1 \%$ reduction in AUC, respectively (Figures 4(e)-4(f)). Ratios of insulin to glucose at 10 minutes after oral glucose loading were also increased significantly in groups treated with $3 \mathrm{mg} / \mathrm{kg}$ and $9 \mathrm{mg} / \mathrm{kg}$ E2HSA (Figure $4(\mathrm{~h})$ ), suggesting improved $\beta$-cell function. Exendin-4 significantly reduced the AUC (e.g., $16.0 \%$ and $13.0 \%$ at 2 nd and 5th weeks, resp.) as well as suppressed blood glucose levels following glucose challenge, as shown in Figures 4(c)-4(f). Glycated hemoglobin, HbAlc, was tested at the end of E2HSA treatment. Compared to $\mathrm{db} / \mathrm{m}$ mice, $\mathrm{db} / \mathrm{db}$ mice in the control group displayed elevated HbAlc levels. On the 37th day of treatment, $3 \mathrm{mg} / \mathrm{kg}$ and $9 \mathrm{mg} / \mathrm{kg}$ E2HSA both reduced HbAlc levels significantly, indicating efficient glycemic control over the entire course of treatment (Figure $4(\mathrm{~g})$ ). On the other hand, exendin-4 was unable to show a significant HbAlc lowering effect at the same time (Figure 4(g)).

\subsection{Long-Term Treatment of E2HSA Increased Insulin Secre-} tion, Reduced Plasma Glucagon Levels, and Decreased the
Plasma Lipid Profile. Chronic E2HSA treatment dose-dependently increased fasting plasma insulin levels in $\mathrm{db} / \mathrm{db}$ mice (Figure 5(a)), while fasting plasma glucagon levels in E2HSA-treated groups showed an overall trend towards reduction (decreased by $28.0 \%, 23.7 \%$, and $24.1 \%$ for $1 \mathrm{mg} / \mathrm{kg}$, $3 \mathrm{mg} / \mathrm{kg}$, and $9 \mathrm{mg} / \mathrm{kg}$ E2HSA, resp.) but with no dosedependency (Figure 5(c)). Exendin-4-treated $\mathrm{db} / \mathrm{db}$ mice displayed enhanced insulin secretion, while their plasma glucagon levels were comparable to the control group. To determine whether E2HSA treatment could increase phase I insulin secretion, we measured the acute insulin-secretory response to glucose by utilizing a simplified IVGTT. Blood samples taken at 2 minutes, 5 minutes, and 8 minutes after glucose challenge were analyzed. Insulin levels at 2 minutes were higher than those at 5 minutes and 8 minutes (insulin levels at 8 minutes were the lowest and not shown). Both $3 \mathrm{mg} / \mathrm{kg}$ and $9 \mathrm{mg} / \mathrm{kg}$ doses of E2HSA produced a significant increase in plasma insulin levels at 2 minutes (Figure 5(b)). Since first-phase insulin secretion occurs within the first 10 minutes after glucose infusion, we could conclude that chronic E2HSA and exendin-4 treatment significantly increased first-phase insulin secretion. During the treatment, E2HSA also significantly reduced fasting plasma triglyceride levels on the 1st week (not shown), 3rd week (not shown), and 5th week (Figure $5(\mathrm{~d})$ ) in $\mathrm{db} / \mathrm{db}$ mice. Total plasma cholesterol and FFA levels were decreased in the first two weeks (Figures 5(e)-5(f)), but the effects were not sustained in the following weeks (data not shown).

3.5. Chronic E2HSA Treatment Decreased Body Weight, Food Intake, and Water Consumption. During the chronic treatment of $\mathrm{db} / \mathrm{db}$ mice, we monitored changes in body weight 


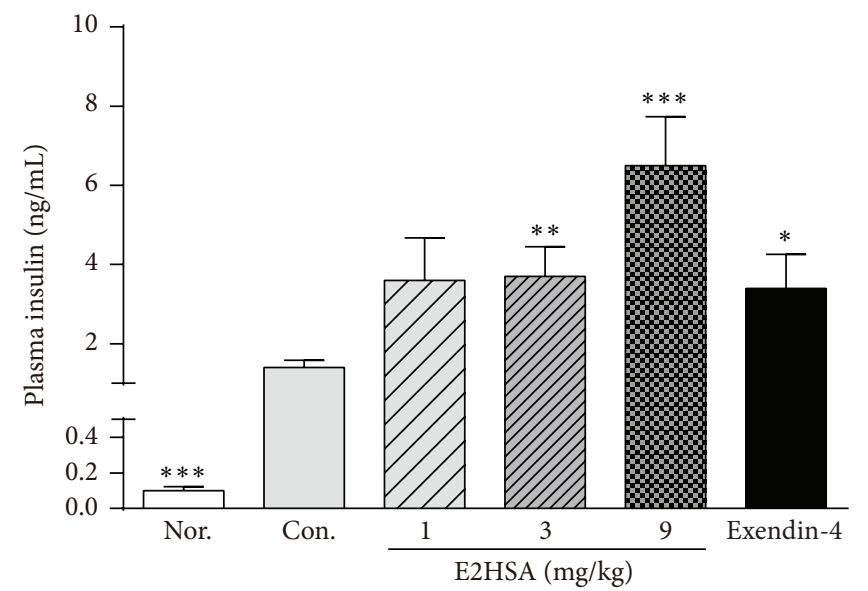

(a)

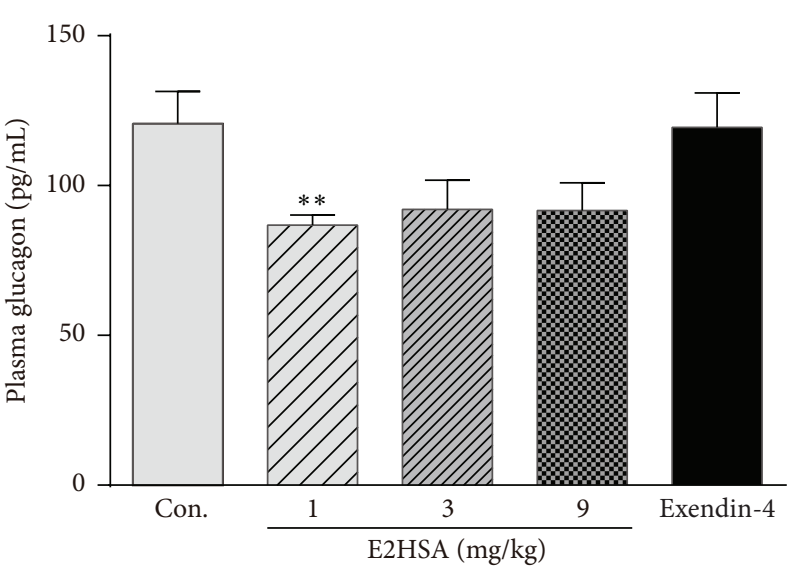

(c)

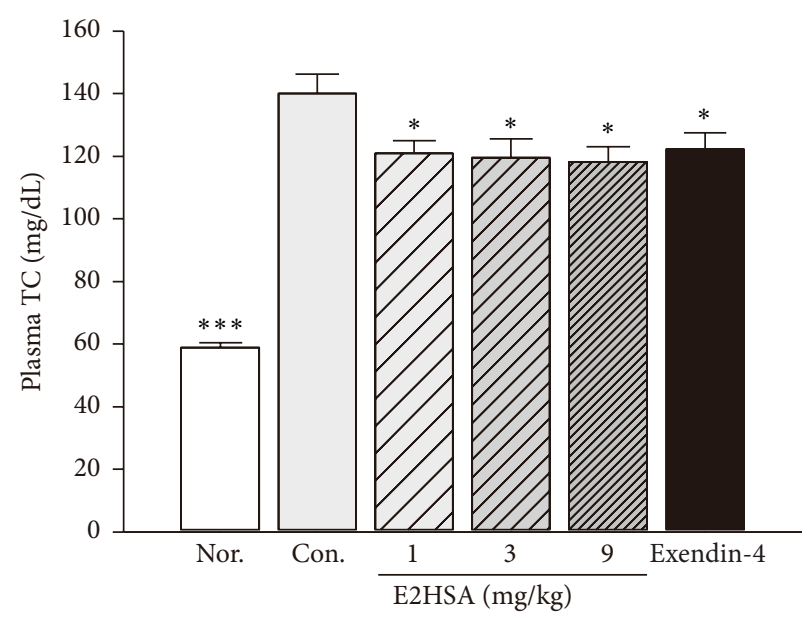

(e)

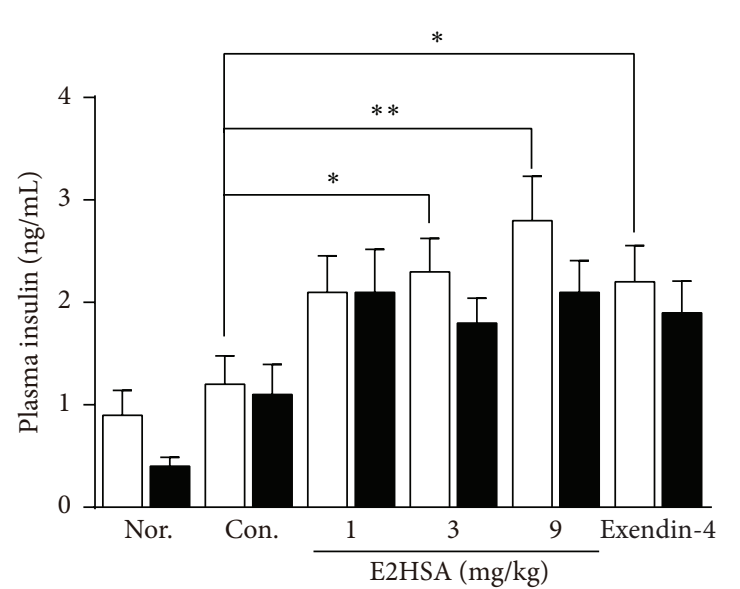

(b)

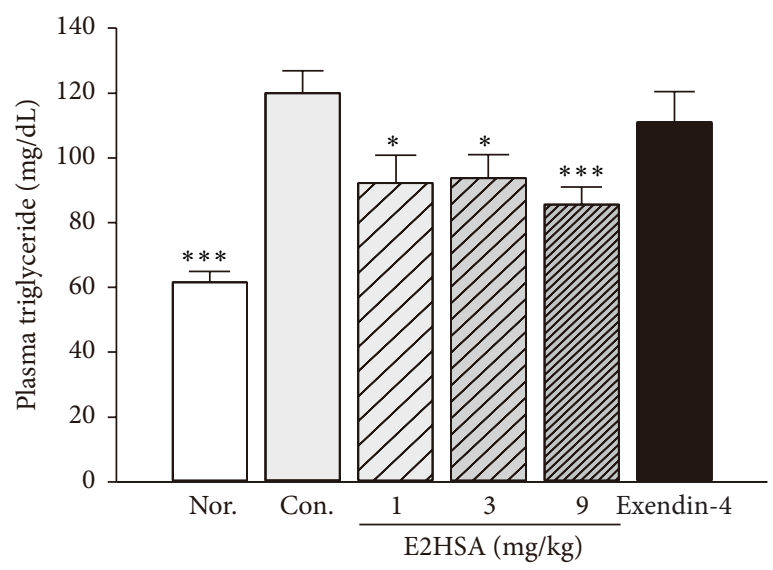

(d)

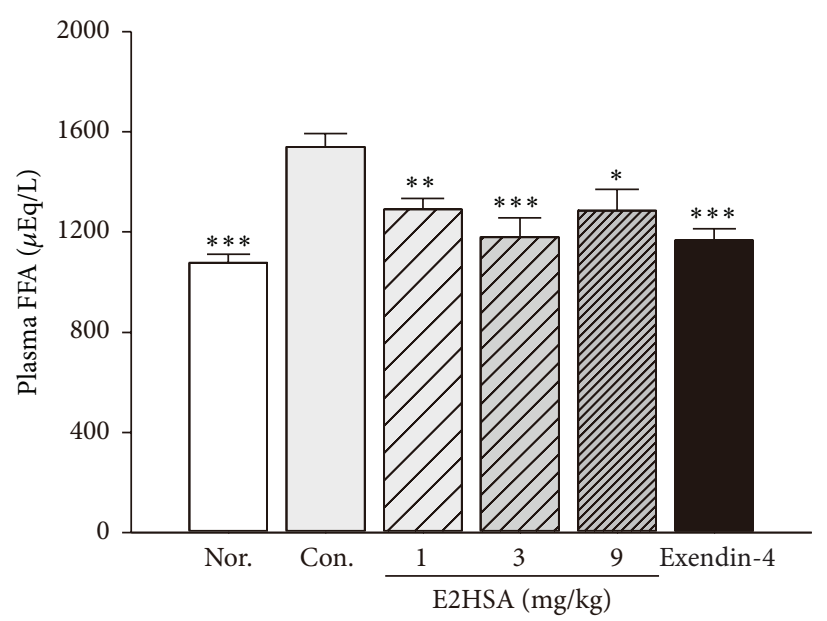

(f)

FIGURE 5: Effects of E2HSA on islet hormone secretion and plasma lipid levels in spontaneous type 2 diabetes db/db mice. (a) Fasting plasma insulin levels at the 2nd week. (b) Plasma insulin levels at 2 minutes and 5 minutes after intravenous glucose challenge in IVGTT. (c) Fasting plasma glucagon levels at the end of the experiment. ((d)-(f)) Fasting plasma triglyceride levels from the 5th week (d), fasting total plasma cholesterol levels from the 1 st week (e), and fasting plasma FFA levels from the 2nd week (f) were represented here. Nor., $\mathrm{db} / \mathrm{m}$ mice administered normal saline. Con., db/db mice administered normal saline. Data are expressed as mean \pm S.E.M $(n=10-11)$. ${ }^{*} P<0.05$, ${ }^{* *} P<0.01$, and ${ }^{* * *} P<0.001$ versus $C o n$. 


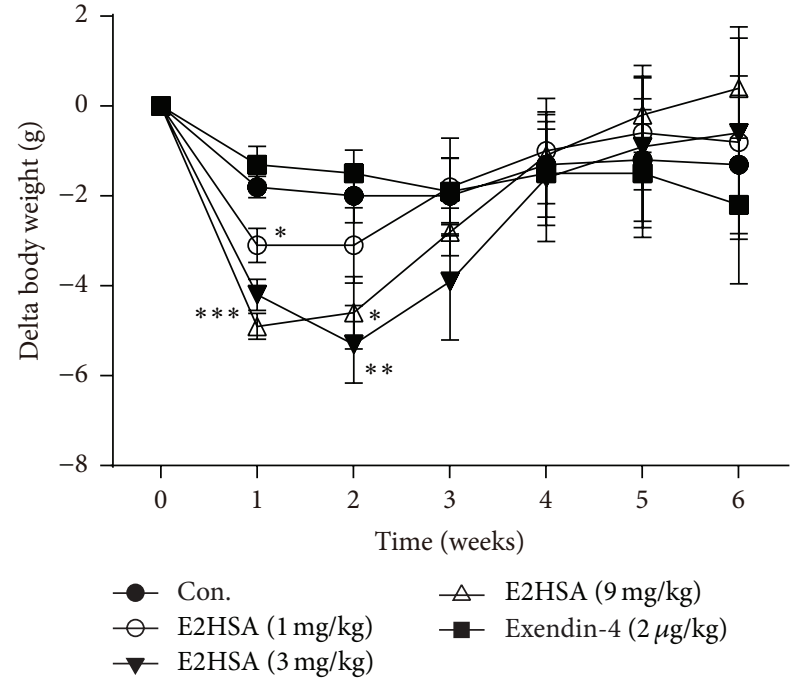

(a)

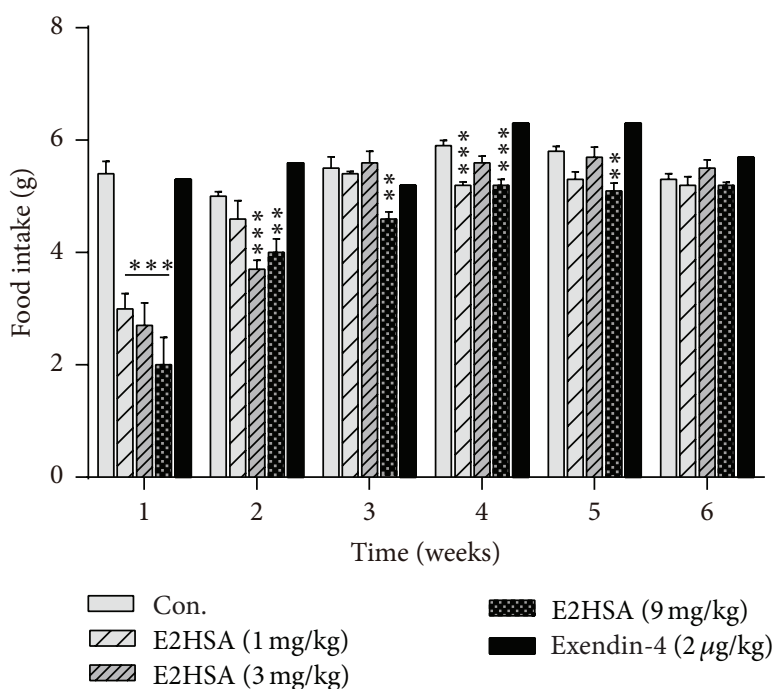

(b)

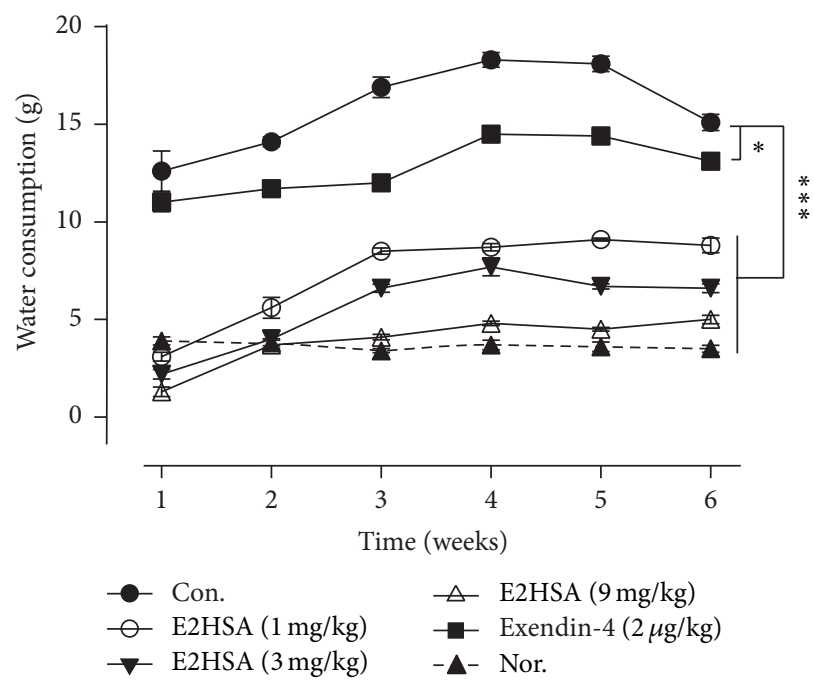

(c)

FIGURE 6: Chronic treatment with E2HSA decreased average body weight, inhibited average food, and water intake in spontaneous type 2 diabetes db/db mice. (a) Delta body weight change per mouse per week. (b) Average food intake per mouse per week. (c) Average water consumption per mouse per week. Con., db/db mice administered normal saline. Data are expressed as mean \pm S.E.M $(n=10-11)$. ${ }^{*} P<0.05$, ${ }^{* *} P<0.01$, and ${ }^{* * *} P<0.001$ versus Con.

and food and water intake every day. As shown in Figure 6(a), E2HSA significantly decreased body weight in the first two weeks, although this effect diminished gradually. Body weight in the exendin-4-treated group showed only a very modest declining trend at the end of treatment. Food intake in all E2HSA-treated mice was significantly reduced in the first week. Interestingly, $9 \mathrm{mg} / \mathrm{kg}$ E2HSA maintained this effect until the 5th week, while the other two doses gradually lost efficacy (Figure 6(b)). On the other hand, Figure 6(c) showed that there was extensive water consumption in vehicle treated $\mathrm{db} / \mathrm{db}$ mice compared to $\mathrm{db} / \mathrm{m}$ mice, suggesting that diabetes-induced polydipsia might exist in these mice. E2HSA significantly reduced water consumption in a dosedependent manner throughout the treatment (Figure 6(c)).
3.6. Chronic Treatment with E2HSA Restored $\beta$-Cell Morphology, Increased $\beta$-Cell Area, and Inhibited $\beta$-Cell Apoptosis. Long-term treatment with E2HSA in $\mathrm{db} / \mathrm{db}$ mice improved glucose tolerance and stimulated first-phase insulin secretion, suggesting an enhancement in $\beta$-cell function. To determine whether E2HSA had any effect on islet morphology and $\beta$-cell area, we double-stained islets with anti-insulin and anti-glucagon antibodies. As previously reported, islet morphology was impaired in $\mathrm{db} / \mathrm{db}$ mice. Compared to $\mathrm{db} / \mathrm{m}$ mice, $\beta$-cell area in $\mathrm{db} / \mathrm{db}$ mice was less and the normal distribution of $\alpha$-cells and $\beta$-cells was also perturbed. Intriguingly, E2HSA treatment significantly increased $\beta$-cell area and restored normal distribution of $\alpha$-cells and $\beta$ cells, with $\alpha$-cells on the outside and $\beta$-cells on the inside 
(Figures 7(a) and 7(c)). TUNEL assay revealed that chronic E2HSA treatment reduced the ratio of TUNEL positive nuclei to insulin positive $\beta$-cells, suggesting that $\beta$-cell apoptosis was also reduced (Figures 7(b) and 7(d)).

\subsection{Chronic E2HSA Treatment Improved $\beta$-Cell Function and} Survival That Correlates with the Regulation of Genes and Proteins Associated with Proliferation and Apoptosis. Since chronic E2HSA treatment significantly increased $\beta$-cell area in $\mathrm{db} / \mathrm{db}$ mice, we next used quantitative real-time PCR and Western blot to investigate whether the expressions of genes and proteins associated with $\beta$-cell survival and apoptosis were affected by E2HSA using samples made from the pancreas tail section. As shown in Figure 8, expression of Irs2, an essential component of the GLP-1 and insulin signaling pathways, was increased by 1.8 -fold and 1.7-fold in E2HSA $(9 \mathrm{mg} / \mathrm{kg}$ ) and exendin- 4 treated groups, respectively. Another downstream target of GLP-1, Pdx-1, was also upregulated by E2HSA ( $9 \mathrm{mg} / \mathrm{kg})$. Bcl-2 family proteins are critical to $\beta$-cell survival and linked to GLP-1R activation. The proapoptotic factors, $\mathrm{BAD}$ and $\mathrm{Bim}$, interact with $\mathrm{Bcl}-\mathrm{XL} / \mathrm{Bcl}-2$ and result in cell death, while phosphorylated $\mathrm{BAD}(\mathrm{pBAD})$ is the inactive form and thus correlates with less death. We have demonstrated that E2HSA $(9 \mathrm{mg} / \mathrm{kg})$ treatment significantly increased pBAD (Ser112)/BAD ratios and decreased Bim expression levels (Figures 9(a)-9(b)), whereas prosurvival Bcl-XL protein expression levels were significantly upregulated and expression of Bcl-2 displayed a tendency towards enhancement (Figures 9(c)-9(d)). At the same time, E2HSA treatment also promoted the phosphorylation of an upstream regulator of $\mathrm{BAD}, \mathrm{Erk1} / 2$, which phosphorylates $\mathrm{BAD}$ at Serl12, thus further reducing proapoptotic signals (Figure 9(e)). FoxO1 plays an important role in $\beta$-cell apoptosis and phosphorylation of FoxO1 leads to its inactivation. After chronic treatment with E2HSA, the pFoxO1/FoxO1 ratio was greatly augmented in $\mathrm{db} / \mathrm{db}$ mice islets, indicating its activity was inhibited (Figure 9(f)). In accordance with increased insulin secretion, the expression levels of two important genes involved in the regulation of insulin biosynthesis and secretion, Nkx6.1 and MafA, were both significantly increased by about 1.8-fold after E2HSA treatment (Figure 8). E2HSA also upregulated Ins2 and Igf1, two genes which are involved in insulin-induced signaling pathways.

\section{Discussion}

GLP-1 based therapies drew a lot of attention in recent years due to its preferable clinical efficacies and unique action mechanisms. GLP-1R agonists have the advantage of simultaneously stimulating insulin secretion while inhibiting gastric emptying, which eventually leads to effective blood glucose control and weight loss [6]. Therefore, GLP-1R agonists such as exendin- 4 and liraglutide represent a promising drug class and have been recommended as the second-line therapy for T2DM patients [23]. However, exendin- 4 is relatively shortlived in vivo. Therefore, long-acting GLP-1 receptor agonists which can extend circulating time and reduce injection frequency are highly sought after in the clinic.
E2HSA is a recombinant protein generated by the fusion of two tandem exendin-4 peptides with human serum albumin, a configuration which significantly increases the halflife of exendin-4. In the present study, E2HSA could activate GLP-1 receptor and displayed a prolonged biological acting time in vivo. Utilizing luciferase reporter gene expression assays, we demonstrated that E2HSA not only retained the ability of exendin- 4 to activate GLP-1R but also showed the same efficacy as exendin-4, suggesting that altered peptide conformation did not prevent exendin-4 from recognizing and activating the GLP-1 receptor. For its long-acting effects, we observed the lasting time of its glucose lowering effect in vivo shown by suppression of blood glucose levels after oral glucose challenge and reduction in nonfasting blood glucose levels. Compared to exendin-4, the circulating time of E2HSA was much longer and, according to our study, the effect of E2HSA on blood glucose could last up to 4 days in ICR mice. The inhibition of gastric emptying could also last at least 3 days. Thus, with the fusion of HSA, the duration of E2HSA's biological activity in vivo was significantly prolonged. Moreover, our results were further supported by the study of Zhang and colleagues [24]. They demonstrated that, in healthy rhesus monkeys, the biological half-life of E2HSA was approximately $54 \mathrm{~h}$ following subcutaneous administration, whereas exendin- 4 had a much shorter halflife of $60 \mathrm{~min}$.

Zhang et al. also evaluated the acute effects of E2HSA in healthy monkeys. After a single injection, E2HSA reduced fasting and nonfasting blood glucose levels, improved glucose tolerance, and decreased food intake. Using a hyperglycemic clamp, E2HSA also augmented insulin secretion, indicating improved $\beta$-cell function. All aforementioned effects lasted significantly longer than those using unmodified exendin-4. In our study, chronic treatment with E2HSA in spontaneous $\mathrm{db} / \mathrm{db}$ mice revealed similar effects. The glucose lowering effect of E2HSA was robust, while glucose tolerance and $\beta$ cell function were improved and ultimately food intake and body weight were both greatly reduced. In addition, we also found that E2HSA could reduce apoptosis and promote $\beta$-cell survival.

E2HSA possessed the pharmacological actions of a GLP$1 \mathrm{R}$ agonist shown by improved glycemic control as well as by a reduction in HbAlc levels in chronic treatment. While $3 \mathrm{~m} / \mathrm{kg}$ and $9 \mathrm{mg} / \mathrm{kg}$ doses of E2HSA significantly reduced HbAlc levels, the effect was not as remarkable with $1 \mathrm{mg} / \mathrm{kg}$ dose of E2HSA and was not also as remarkable in exendin-4-treated groups. $\mathrm{HbAlc}$ reflects the average blood glucose levels in the previous 2-3 months [25]. As our HbAlc data were obtained on the 37th day, just over 1 month, such data might have reflected the glycemic conditions before E2HSA and exendin4 administration. It is also worth noting that the nonfasting and fasting blood glucose levels in $1 \mathrm{mg} / \mathrm{kg}$ E2HSA and exendin-4-treated groups were more variable in the 3rd week to 5th week, so it is possible that the effect on HbAlc levels was less significant. In fact, a recent study has demonstrated that after 4 weeks of treatment with exendin- $4(24 \mathrm{nmol} / \mathrm{kg})$, HbAlc levels were not reduced in high-fat diet-fed mice [15]. Moreover, in another study [26], after 12-13 weeks of treatment, exendin-4 (24 nmol/kg) significantly decreased HbAlc 

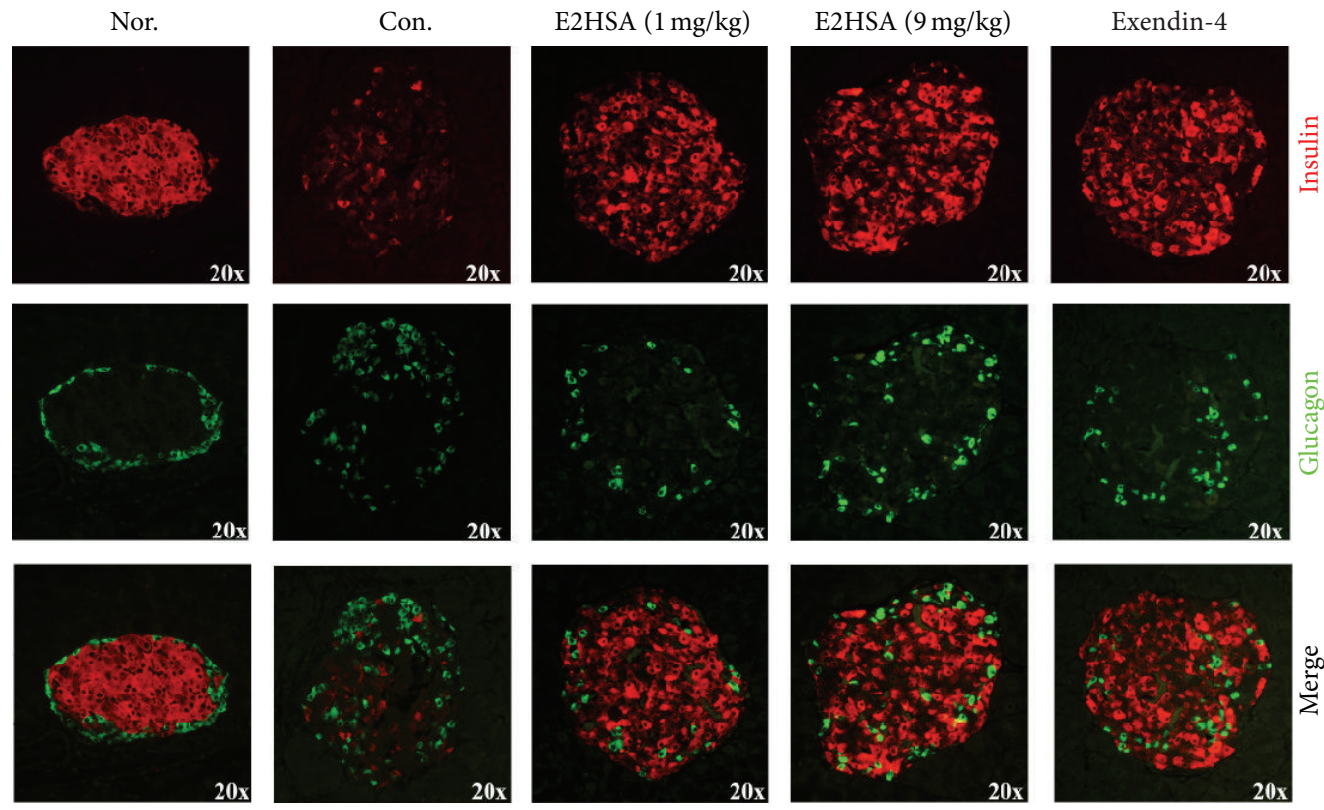

(a)
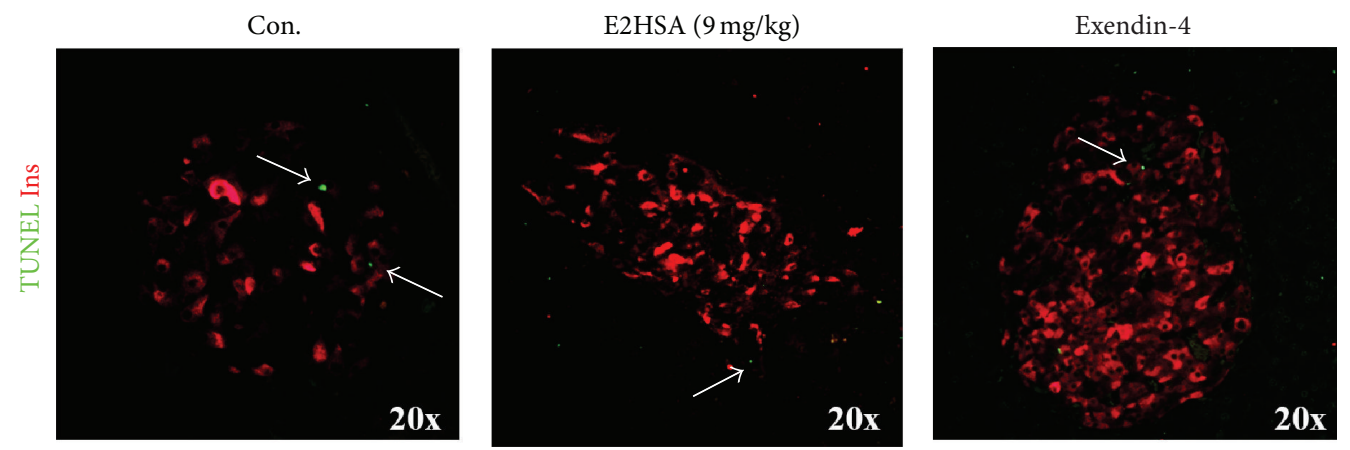

(b)

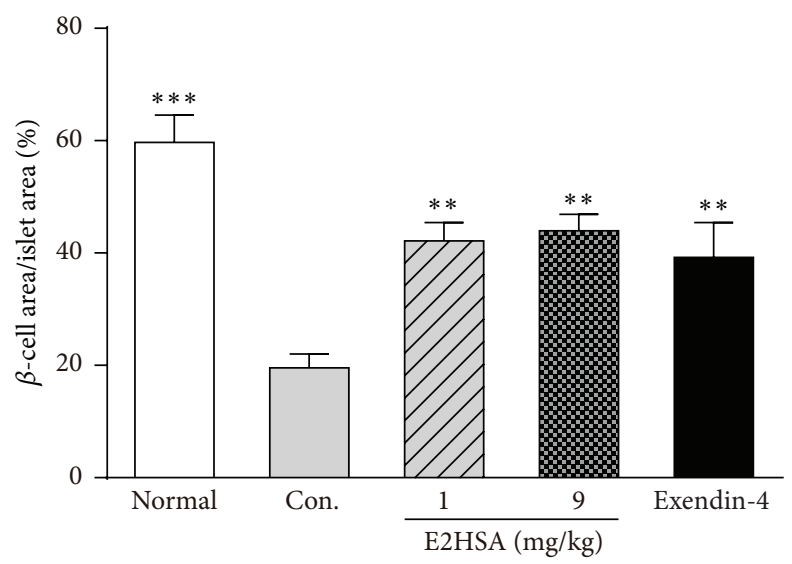

(c)

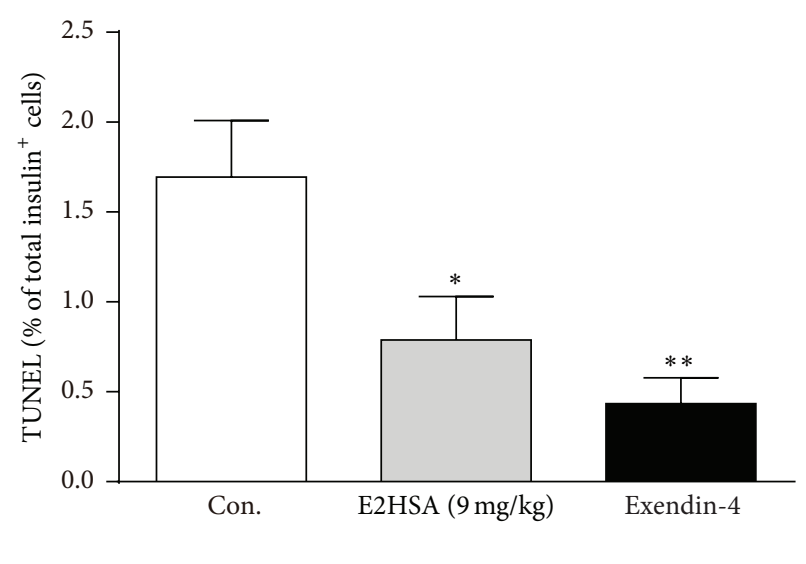

(d)

FIGURE 7: Chronic treatment with E2HSA normalized islet morphology, increased $\beta$-cell area, and inhibited $\beta$-cell apoptosis in spontaneous type 2 diabetes $\mathrm{db} / \mathrm{db}$ mice. (a) Immunofluorescence double staining with anti-insulin and anti-glucagon antibodies on pancreatic sections. (b) TUNEL assay on $\beta$-cells costained with anti-insulin antibodies. Representative images are shown. (c) Total $\beta$-cell area as percentage of total islet areas $(n=5)$. (d) Percentage of TUNEL positive $\beta$-cells in insulin positive cells $(n=3$ per group). Data are expressed as mean \pm S.E.M. ${ }^{*} P<0.05$ and ${ }^{* *} P<0.01$ versus Con. 


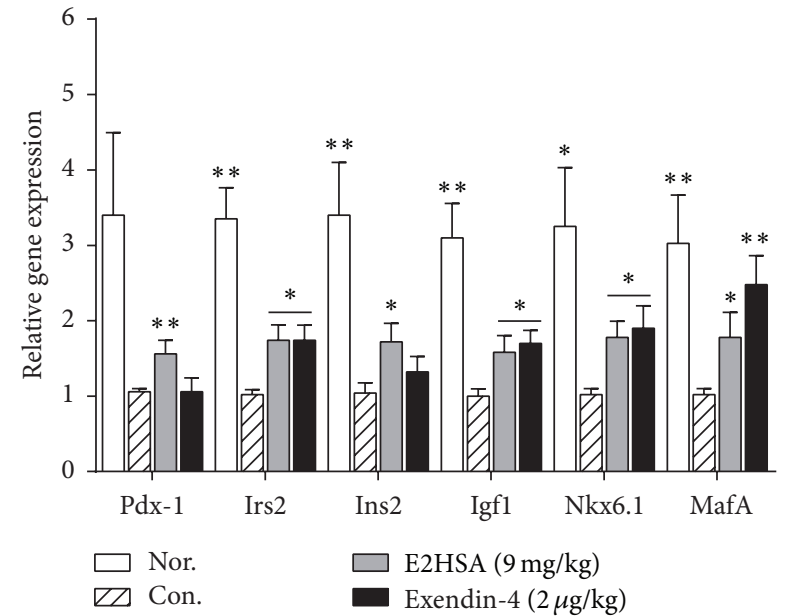

FIGURE 8: Expression of genes related to $\beta$-cell function and survival in spontaneous type 2 diabetes $\mathrm{db} / \mathrm{db}$ mice treated with E2HSA. Data were from pancreas tail samples. Gene expression was analyzed by quantitative real-time PCR. A comparative cycle threshold (CT) method was used for relative quantification of gene expression between different groups using $\beta$-actin for normalization. Data are expressed as mean \pm S.E.M $(n=4-5) .{ }^{*} P<0.05$ and ${ }^{* *} P<0.01$ versus Con.

levels in $\mathrm{db} / \mathrm{db}$ mice $\left(\right.$ C57BLKS/J-Lepr ${ }^{\mathrm{db}} /$ Lepr $^{\mathrm{db}}$ ). Therefore, it is possible that if $1 \mathrm{mg} / \mathrm{kg}$ E2HSA or exendin- 4 was given for a longer time, we might be able to observe its obvious HbAlc lowering effects.

Consistent with other GLP-1R agonists [26, 27], E2HSA dose-dependently increased plasma insulin levels and firstphase insulin secretion. Fasting plasma glucagon levels were decreased to some extent after E2HSA treatment, while in exendin-4-treated groups, the change was negligible. Although in clinical studies all GLP-1R agonists could inhibit glucagon secretion to varying degrees, few have measured plasma glucagon levels in experimental animals. Baggio et al. [20] reported that Albugon, another long-acting GLP$1 \mathrm{R}$ agonist, did not reduce plasma glucagon levels in mice fasted overnight. The same was also seen for CJC1134-PC [15]. However, another study [28] demonstrated that exenatide reduced basal plasma glucagon levels during a $30 \mathrm{~min}$ intravenous infusion $(2.6 \mu \mathrm{g} / \mathrm{h})$ period in diabetic obese Zucker rats. Therefore, the effect of E2HSA on glucagon secretion needs to be further investigated.

Treatments with GLP-1R agonists are also associated with weight loss, which can be partly attributed to their ability to delay gastric emptying and increase satiety. As for E2HSA, the inhibition of gastric emptying lasted to the 3rd day after a single administration in ICR mice, which was notably longer than that achieved with exendin-4. A single administration of E2HSA in healthy monkeys also decreased food intake for about 4 days [24]. Furthermore, with chronic treatment in $\mathrm{db} / \mathrm{db}$ mice, E2HSA was able to reduce body weight in the first two weeks but had no effect in the following weeks. The reduction in food intake displayed a similar pattern. Among other long-acting GLP-1R agonists, HFD-fed mice treated for 4 weeks with CJC-1134-PC [15] lost weight, but another GLP-1-albumin conjugate, CJC-1131 [21], failed to reduce body weight during 4 weeks of administration in $\mathrm{db} / \mathrm{db}$ mice. Considering the fact that HSA is too large to cross the blood-brain barrier, such results can be partly explained by the indirect activation of GLP-1R through vagal afferent pathways. Anti-E2HSA antibodies may also play a part since the titers were much higher in the last three weeks (data not shown). It is of note that water consumption was significantly reduced throughout the study. These results are in line with clinical observations that thirst and polydipsia are linked to blood glucose levels in diabetic subjects, and the reduction could be the result of lower plasma glucose levels or improved glucose tolerance. Thorkildsen and colleagues [29] observed that the GLP-1 receptor agonist, ZP10A, improved glucose tolerance and decreased water consumption in $\mathrm{db} / \mathrm{db}$ mice but had no effect on body weight. However, it is also possible that the reduction in water consumption contributed to the body weight loss we observe, but we cannot be sure as no further investigations were carried out in our study. Perhaps, for example, mice in E2HSA-treated groups urinated less? In fact one study [30] has shown that urine volume was decreased by exendin- $4(1 \mathrm{nmol} / \mathrm{kg})$ treatment. So the relationship between water consumption and body weight needs to be further investigated. In addition, we did not observe any significant weight reduction in exendin4 -treated $\mathrm{db} / \mathrm{db}$ mice. Other studies have observed similar results. In $\mathrm{db} / \mathrm{db}$ mice treated with exendin- $4(24 \mathrm{nmol} / \mathrm{kg})$ for 13 weeks [26] or with NN2211 (liraglutide) twice daily for 15 days [27] there was no significant reduction in body weight with either treatment. However, in rats $(3,10$, and $30 \mu \mathrm{g} / \mathrm{kg} /$ day) and HFD C57BL/6J mice (10 and $30 \mu \mathrm{g} / \mathrm{kg} /$ day) [31], chronic treatment with exendin-4 for 28 days reduced body weight. So the mechanisms behind such controversial and contradictory observations still need to be fully elucidated.

GLP-1R agonists exert their pharmacological effects through multiple signal transduction pathways. In this study, we found that inhibition of $\beta$-cell apoptosis by E2HSA correlates well with the modulation of Bcl-2 family proteins. Bcl-2 and $\mathrm{Bcl}-\mathrm{XL}$, which are prosurvival factors, were upregulated, while BH3-only proteins, such as the proapoptotic factors, $\mathrm{BAD}$ and Bim, were downregulated [32]. Other studies have also reported that GLP-1R activation reduced apoptosis via increased expression of Bcl-2 and Bcl-XL [33]. BH3-only proteins function as initial sensors of apoptotic signals that emanate from various cellular processes [32] and interact with core $\mathrm{Bcl}-2$ family proteins to promote apoptosis. BAD can heterodimerize with $\mathrm{Bcl}-\mathrm{XL}$ or $\mathrm{Bcl}-2$, replacing $\mathrm{BAX}$ from $\mathrm{Bcl}-2 / \mathrm{Bcl}-\mathrm{XL}$, thus neutralizing their protective, prosurvival effects and promoting cell death [34]. Once phosphorylated, pBAD is sequestered in the cytosol and apoptosis is blocked [34]. Hyperglycemia/glucotoxic stress increased BAD protein expression in human and mouse pancreatic islets and caused $\beta$-cell death [35]. Bim also induces apoptosis and can also interact with both $\mathrm{Bcl}-2$ and $\mathrm{Bcl}-\mathrm{XL}$ to antagonize their antiapoptotic activity [36]. Bim was found to mediate $\beta$ cell apoptosis induced by chronic exposure to high glucose [37]. Ren et al. [38] demonstrated that a knock-down of 


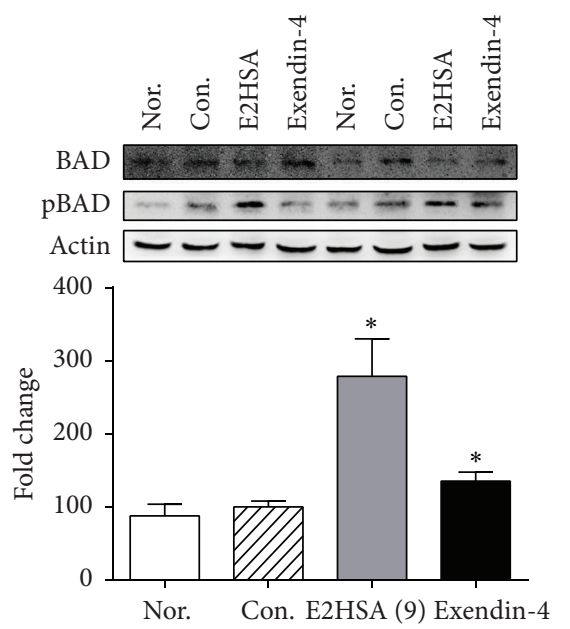

(a)
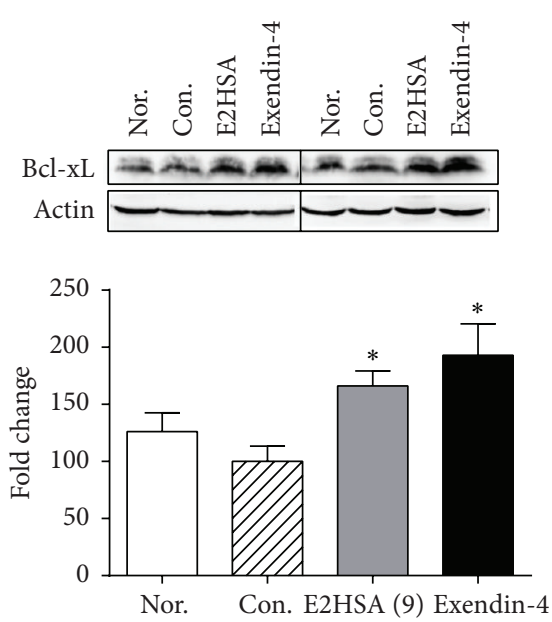

(c)
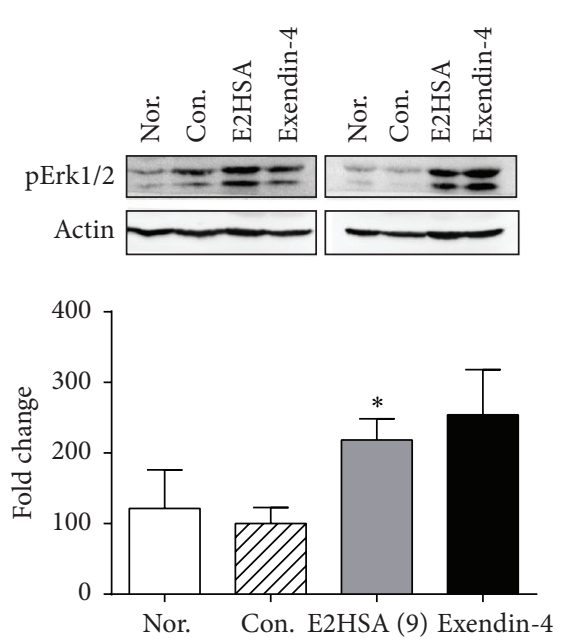

(e)

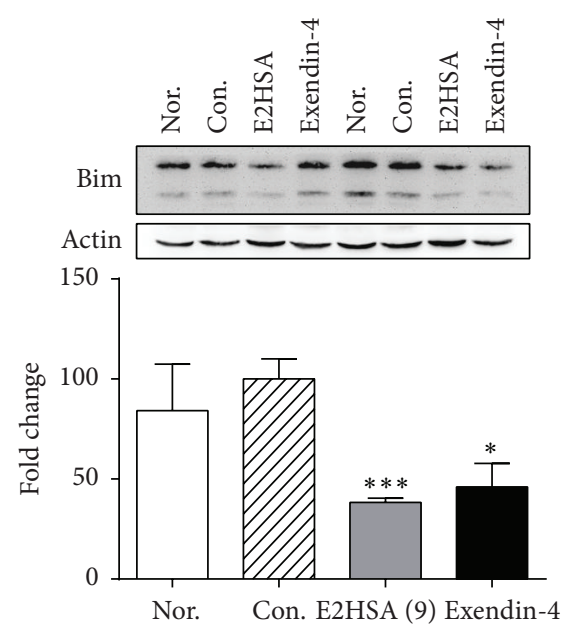

(b)
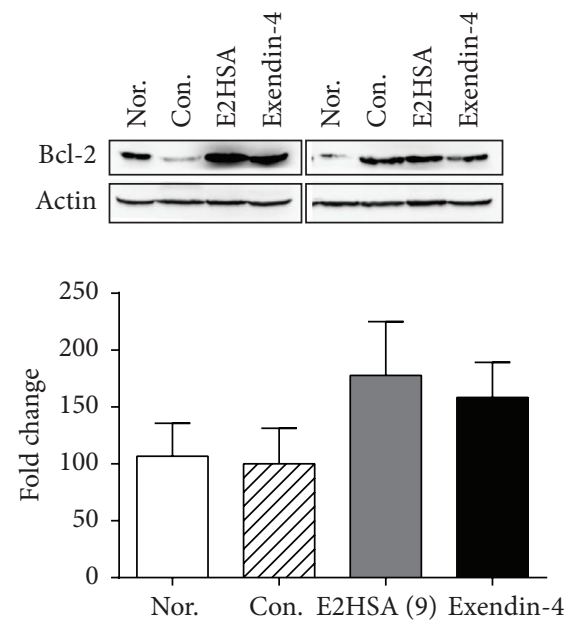

(d)
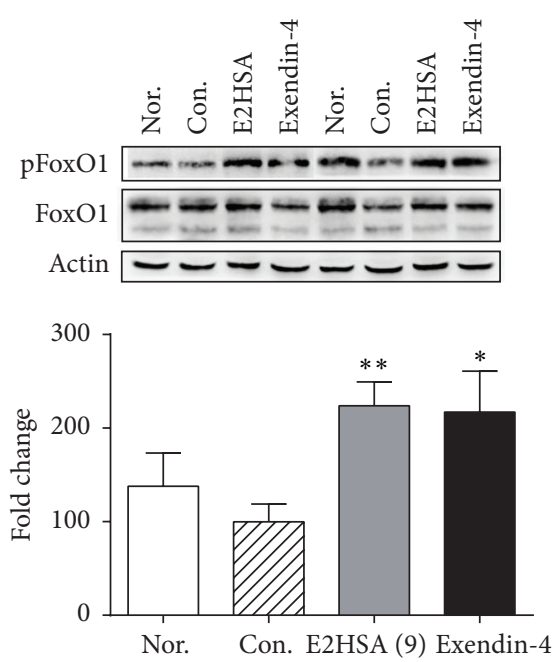

(f)

FIGURE 9: Chronic treatment with E2HSA regulated the expression of Bcl-2 family proteins and FoxO1. Data are from pancreas tail samples. ((a)-(f)) The upper panels show 2 representative Western blots from each group. Protein bands were determined by densitometry analysis and expressed as fold change, after correction for $\beta$-actin expression levels, relative to Con. mice. ((a), (f)) The ratio of phosphorylated protein to total protein of each group was first determined; then the fold change was calculated by comparing to Con. mice. Nor., $\mathrm{db} / \mathrm{m}$ mice treated with normal saline. Con., db/db mice treated with normal saline. E2HSA (9), db/db mice treated with $9 \mathrm{mg} / \mathrm{kg}$ E2HSA. Data are expressed as mean \pm S.E.M $(n=4-5) .{ }^{*} P<0.05,{ }^{* *} P<0.01$, and ${ }^{* * *} P<0.001$ versus Con. 
Bim significantly reduced $\beta$-cell apoptosis, preserved $\beta$ cell mass, and restored normal glucose tolerance in Irs $2^{-/-}$ mice. Such processes also involve FoxO1, a transcription factor which had been shown to contribute to apoptosis by increasing transcription of Bim [39]. Importantly, in our study, expression levels of Bim were decreased and levels of phosphorylated FoxO1 were augmented in E2HSA-treated groups. Additionally, Irs2 gene expression was upregulated. FoxO1 is also directly involved in the proliferative and antiapoptotic actions of GLP-1 in $\beta$-cells [40]. Exendin-4 failed to stimulate $\beta$-cell replication or expansion of islet mass in transgenic mice with constitutive expression of FoxO1 in the nucleus [39], where its transcriptional activity was constantly activated [41, 42].

In addition to Irs2, there was also a significant increase in Ins2 and Igf1 gene expression levels upon E2HSA treatment. Irs2 (insulin receptor substrate 2) mediates the effects of insulin and Igf1 on $\beta$-cell growth and function [43], and Irs2 expression was strongly induced in $\beta$-cells by exendin4 [44]. Upregulation of Irs2, Ins2, and Igf1 confirmed the improvement of $\beta$-cell function after E2HSA treatment. Pdx1 is a critical regulator of mature $\beta$-cell function [45] and an important target for GLP-1. Exendin-4 failed to stimulate $\beta$ cell proliferation or inhibit apoptosis in $\mathrm{Pdx}-1^{-/-}$islets [46]. It is thought that GLP-1 regulates Pdx-1 expression through the Irs2 signaling pathway [47]. FoxO1 may also play an important role in this process as Kitamura and colleagues [48] reported that FoxO1 reversed $\beta$-cell dysfunction in Irs $2^{-/-}$ mice through partial restoration of $\beta$-cell proliferation and increased expression of Pdx-1.

Additionally, in vitro studies have suggested that the $\beta$ cell-enriched transcription factor, Nkx6.1, is involved in the regulation of insulin biosynthesis and secretion as well as $\beta$-cell proliferation $[49,50]$. Moreover, MafA is an important factor for $\beta$-cell maturation, glucose-stimulated insulin secretion, and $\beta$-cell function [51], and its expression was decreased in $\mathrm{db} / \mathrm{db}$ mice [52] coupled with reduced insulin secretion. Therefore, these two genes also contributed to the beneficial pharmacological effects of E2HSA on $\beta$-cells. Furthermore, Quoyer et al. [53] demonstrated in $\beta$-cells that GLP-1 activates the ERK1/2 cascade which then ultimately phosphorylates BAD at Serl12 and that this process protects $\beta$-cells against apoptosis. In our study, we observed a significant increase in PBAD (Ser112)/BAD ratio and phosphorylated ERK1/2 after E2HSA treatment. Thus we suspect E2HSA might exert its antiapoptotic effect partly through the ERK1/2 pathway.

\section{Conclusion}

The current preclinical study demonstrated that the recombinant fusion protein of exendin- 4 and human serum albumin (E2HSA) retained the ability of exendin-4 to activate GLP-1 receptor with similar efficacy. E2HSA also displayed a much longer glucose lowering effect and a longer gastric emptying inhibitory effect in vivo. Chronic treatment confirmed its beneficial effects on glycemic control and insulin secretion as well as $\beta$-cell function and $\beta$-cell area. Importantly, $\beta$-cell apoptosis was also reduced and $\beta$-cell survival was promoted. Our data suggests that this novel, long-acting GLP-1R agonist possesses high antidiabetic potency and supports further assessment for once weekly treatment in T2DM patients.

\section{Conflict of Interests}

The authors declare that there is no conflict of interests regarding the publication of this paper.

\section{References}

[1] S. E. Kahn, "The relative contributions of insulin resistance and beta-cell dysfunction to the pathophysiology of Type 2 diabetes," Diabetologia, vol. 46, no. 1, pp. 3-19, 2003.

[2] M. M. Sachdeva, K. C. Claiborn, C. Khoo et al., "Pdx1 (MODY4) regulates pancreatic beta cell susceptibility to ER stress," Proceedings of the National Academy of Sciences of the United States of America, vol. 106, no. 45, pp. 19090-19095, 2009.

[3] J. P. Hosker, A. S. Rudenski, M. A. Burnett, D. R. Matthews, and R. C. Turner, "Similar reduction of first- and second-phase Bcell responses at three different glucose levels in type II diabetes and the effect of gliclazide therapy," Metabolism: Clinical and Experimental, vol. 38, no. 8, pp. 767-772, 1989.

[4] A. E. Butler, J. Janson, S. Bonner-Weir, R. Ritzel, R. A. Rizza, and P. C. Butler, " $\beta$-cell deficit and increased $\beta$-cell apoptosis in humans with type 2 diabetes," Diabetes, vol. 52, no. 1, pp. 102110, 2003.

[5] J. J. Holst, “The physiology of glucagon-like peptide 1," Physiological Reviews, vol. 87, no. 4, pp. 1409-1439, 2007.

[6] D. J. Drucker and M. A. Nauck, "The incretin system: glucagonlike peptide-1 receptor agonists and dipeptidyl peptidase-4 inhibitors in type 2 diabetes," The Lancet, vol. 368, no. 9548, pp. 1696-1705, 2006.

[7] A. R. Meloni, M. B. Deyoung, C. Lowe, and D. G. Parkes, "GLP1 receptor activated insulin secretion from pancreatic betacells: mechanism and glucose dependence," Diabetes, Obesity \& Metabolism, vol. 15, no. 1, pp. 15-27, 2013.

[8] J. E. Campbell and D. J. Drucker, "Pharmacology, physiology, and mechanisms of incretin hormone action," Cell Metabolism, vol. 17, no. 6, pp. 819-837, 2013.

[9] C. Orskov, A. Wettergren, and J. J. Holst, "Biological effects and metabolic rates of glucagonlike peptide-1 7-36 amide and glucagonlike peptide-1 7-37 in healthy subjects are indistinguishable," Diabetes, vol. 42, no. 5, pp. 658-661, 1993.

[10] T. Vilsbøll, H. Agersø, T. Krarup, and J. J. Holst, "Similar elimination rates of glucagon-like peptide-1 in obese type 2 diabetic patients and healthy subjects," Journal of Clinical Endocrinology and Metabolism, vol. 88, no. 1, pp. 220-224, 2003.

[11] C. F. Deacon, L. B. Knudsen, K. Madsen, F. C. Wiberg, O. Jacobsen, and J. J. Holst, "Dipeptidyl peptidase IV resistant analogues of glucagon-like peptide-1 which have extended metabolic stability and improved biological activity," Diabetologia, vol. 41, no. 3, pp. 271-278, 1998.

[12] J. Eng, W. A. Kleinman, L. Singh, G. Singh, and J.-P. Raufman, "Isolation and characterization of exendin-4, an exendin-3 analogue, from Heloderma suspectum venom: further evidence for an exendin receptor on dispersed acini from guinea pig pancreas," The Journal of Biological Chemistry, vol. 267, no. 11, pp. 7402-7405, 1992. 
[13] R. Göke, H.-C. Fehmann, T. Linn et al., "Exendin-4 is a high potency agonist and truncated exendin-(9-39)-amide an antagonist at the glucagon-like peptide 1-(7-36)-amide receptor of insulin-secreting $\beta$-cells," The Journal of Biological Chemistry, vol. 268, no. 26, pp. 19650-19655, 1993.

[14] O. G. Kolterman, D. D. Kim, L. Shen et al., "Pharmacokinetics, pharmacodynamics, and safety of exenatide in patients with type 2 diabetes mellitus," American Journal of Health-System Pharmacy, vol. 62, no. 2, pp. 173-181, 2005.

[15] L. L. Baggio, Q. Huang, X. Cao, and D. J. Drucker, "An albumin-exendin-4 conjugate engages central and peripheral circuits regulating murine energy and glucose homeostasis," Gastroenterology, vol. 134, no. 4, pp. 1137-1147, 2008.

[16] M. N. Feinglos, M. F. Saad, F. X. Pi-Sunyer, B. An, and O. Santiago, "Effects of liraglutide (NN2211), a long-acting GLP-1 analogue, on glycaemic control and bodyweight in subjects with Type 2 diabetes," Diabetic Medicine, vol. 22, no. 8, pp. 1016-1023, 2005.

[17] M. S. Dennis, M. Zhang, Y. G. Meng et al., "Albumin binding as a general strategy for improving the pharmacokinetics of proteins," The Journal of Biological Chemistry, vol. 277, no. 38, pp. 35035-35043, 2002.

[18] T. Peters Jr., "Serum albumin," Advances in Protein Chemistry, vol. 37, pp. 161-245, 1985.

[19] Y. Huan and Z.-F. Shen, "A novel cell model targeted on GLP-1 receptor for application to anti-diabetic candidates screening," Acta Pharmaceutica Sinica, vol. 44, no. 3, pp. 309-313, 2009.

[20] L. L. Baggio, Q. Huang, T. J. Brown, and D. J. Drucker, "A recombinant human glucagon-like peptide (GLP)-1-albumin protein (Albugon) mimics peptidergic activation of GLP-1 receptor-dependent pathways coupled with satiety, gastrointestinal motility, and glucose homeostasis," Diabetes, vol. 53, no. 9, pp. 2492-2500, 2004.

[21] J.-G. Kim, L. L. Baggio, D. P. Bridon et al., "Development and characterization of a glucagon-like peptide 1-albumin conjugate the ability to activate the glucagon-like peptide 1 receptor in vivo," Diabetes, vol. 52, no. 3, pp. 751-759, 2003.

[22] S. Reagan-Shaw, M. Nihal, and N. Ahmad, "Dose translation from animal to human studies revisited," The FASEB Journal, vol. 22, no. 3, pp. 659-661, 2008.

[23] T. Setji and M. Feinglos, "Albiglutide: clinical overview of a long-acting GLP-1 receptor agonist in the treatment of type 2 diabetes," Expert Review of Endocrinology \& Metabolism, vol. 8, no. 3, pp. 229-238, 2013.

[24] L. Zhang, L. Wang, Z. Meng et al., "A novel exendin-4 human serum albumin fusion protein, E2HSA, with an extended halflife and good glucoregulatory effect in healthy rhesus monkeys," Biochemical and Biophysical Research Communications, vol. 445, no. 2, pp. 511-516, 2014.

[25] American Diabetes Association, "Standards of medical care in diabetes-2011," Diabetes Care, vol. 34, supplement 1, pp. S11S61, 2011.

[26] N. H. Greig, H. W. Holloway, K. A. De Ore et al., "Once daily injection of exendin- 4 to diabetic mice achieves long-term beneficial effects on blood glucose concentrations," Diabetologia, vol. 42, no. 1, pp. 45-50, 1999.

[27] B. Rolin, M. O. Larsen, C. F. Gotfredsen et al., "The long-acting GLP-1 derivative NN2211 ameliorates glycemia and increases $\beta$ cell mass in diabetic mice," American Journal of PhysiologyEndocrinology and Metabolism, vol. 283, no. 4, pp. E745-E752, 2002.
[28] D. G. Parkes, K. F. Mace, and M. E. Trautmann, "Discovery and development of exenatide: the first antidiabetic agent to leverage the multiple benefits of the incretin hormone, GLP-1," Expert Opinion on Drug Discovery, vol. 8, no. 2, pp. 219-244, 2013.

[29] C. Thorkildsen, S. Neve, B. D. Larsen, E. Meier, and J. S. Petersen, "Glucagon-like peptide 1 receptor agonist ZP10A increases insulin mRNA expression and prevents diabetic progression in db/db mice," Journal of Pharmacology and Experimental Therapeutics, vol. 307, no. 2, pp. 490-496, 2003.

[30] C. W. Park, H. W. Kim, S. H. Ko et al., "Long-term treatment of glucagon-like peptide-1 analog exendin-4 ameliorates diabetic nephropathy through improving metabolic anomalies in $\mathrm{db} / \mathrm{db}$ mice," Journal of the American Society of Nephrology, vol. 18, no. 4, pp. 1227-1238, 2007.

[31] C. M. Mack, C. X. Moore, C. M. Jodka et al., "Antiobesity action of peripheral exenatide (exendin-4) in rodents: effects on food intake, body weight, metabolic status and side-effect measures," International Journal of Obesity, vol. 30, no. 9, pp. 1332-1340, 2006.

[32] R. J. Youle and A. Strasser, "The BCL-2 protein family: opposing activities that mediate cell death," Nature Reviews Molecular Cell Biology, vol. 9, no. 1, pp. 47-59, 2008.

[33] H. Hui, A. Nourparvar, X. Zhao, and R. Perfetti, "Glucagonlike peptide-1 inhibits apoptosis of insulin-secreting cells via a cyclic $5^{\prime}$-adenosine monophosphate-dependent protein kinase A- and a phosphatidylinositol 3-kinase-dependent pathway," Endocrinology, vol. 144, no. 4, pp. 1444-1455, 2003.

[34] J. P. Zha, H. Harada, E. Yang, J. Jockel, and S. J. Korsmeyer, "Serine phosphorylation of death agonist $\mathrm{BAD}$ in response to survival factor results in binding to 14-3-3 not BCL- $\mathrm{X}_{\mathrm{L}}$," Cell, vol. 87, no. 4, pp. 619-628, 1996.

[35] Z. Wang and D. C. Thurmond, "PAK1 limits the expression of the pro-apoptotic protein Bad in pancreatic islet $\beta$-cells," FEBS Open Bio, vol. 2, pp. 273-277, 2012.

[36] L. O'Connor, A. Strasser, L. A. O’Reilly et al., "Bim: a novel member of the Bcl-2 family that promotes apoptosis," The EMBO Journal, vol. 17, no. 2, pp. 384-395, 1998.

[37] I. Santin, F. Moore, M. L. Colli et al., "PTPN2, a candidate gene for type 1 diabetes, modulates pancreatic $\beta$-cell apoptosis via regulation of the $\mathrm{BH} 3$-only protein bim," Diabetes, vol. 60, no. 12, pp. 3279-3288, 2011.

[38] D. Ren, J. Sun, L. Mao, H. Ye, and K. S. Polonsky, "BH3only molecule bim mediates beta-cell death in IRS2 deficiency," Diabetes, vol. 63, no. 10, pp. 3378-3387, 2014.

[39] E. L. Greer and A. Brunet, "FOXO transcription factors at the interface between longevity and tumor suppression," Oncogene, vol. 24, no. 50, pp. 7410-7425, 2005.

[40] S. C. Martinez, C. Cras-Méneur, E. Bernal-Mizrachi, and M. A. Permutt, "Glucose regulates Foxol through insulin receptor signaling in the pancreatic islet $\beta$-cell," Diabetes, vol. 55 , no. 6 , pp. 1581-1591, 2006.

[41] T. Kitamura, "The role of FOXO1 in beta-cell failure and type 2 diabetes mellitus," Nature Reviews Endocrinology, vol. 9, no. 10, pp. 615-623, 2013.

[42] D. J. Drucker, "The biology of incretin hormones," Cell Metabolism, vol. 3, no. 3, pp. 153-165, 2006.

[43] M. F. White, "Regulating insulin signaling and $\beta$-cell function through IRS proteins," Canadian Journal of Physiology and Pharmacology, vol. 84, no. 7, pp. 725-737, 2006.

[44] U. S. Jhala, G. Canettieri, R. A. Screaton et al., "cAMP promotes pancreatic $\beta$-cell survival via CREB-mediated induction of 
IRS2," Genes and Development, vol. 17, no. 13, pp. 1575-1580, 2003.

[45] C. S. Lee, N. J. Sund, M. Z. Vatamaniuk, F. M. Matschinsky, D. A. Stoffers, and K. H. Kaestner, "Foxa2 controls Pdx1 gene expression in pancreatic beta-cells in vivo," Diabetes, vol. 51, no. 8, pp. 2546-2551, 2002.

[46] Y. Li, X. Cao, L.-X. Li, P. L. Brubaker, H. Edlund, and D. J. Drucker, " $\beta$-cell Pdxl expression is essential for the glucoregulatory, proliferative, and cytoprotective actions of glucagon-like peptide-1," Diabetes, vol. 54, no. 2, pp. 482-491, 2005.

[47] S. Park, X. Dong, T. L. Fisher et al., "Exendin-4 uses Irs2 signaling to mediate pancreatic beta cell growth and function," The Journal of Biological Chemistry, vol. 281, no. 2, pp. 1159-1168, 2006.

[48] T. Kitamura, J. Nakae, Y. Kitamura et al., "The forkhead transcription factor Foxol links insulin signaling to Pdxl regulation of pancreatic $\beta$ cell growth," The Journal of Clinical Investigation, vol. 110, no. 12, pp. 1839-1847, 2002.

[49] J. C. Schisler, P. B. Jensen, D. G. Taylor et al., “The Nkx6.1 homeodomain transcription factor suppresses glucagon expression and regulates glucose-stimulated insulin secretion in islet beta cells," Proceedings of the National Academy of Sciences of the United States of America, vol. 102, no. 20, pp. 7297-7302, 2005.

[50] J. C. Schisler, P. T. Fueger, D. A. Babu et al., "Stimulation of human and rat islet beta-cell proliferation with retention of function by the homeodomain transcription factor Nkx6.1," Molecular and Cellular Biology, vol. 28, no. 10, pp. 3465-3476, 2008.

[51] Y. Hang and R. Stein, "MafA and MafB activity in pancreatic $\beta$ cells," Trends in Endocrinology and Metabolism, vol. 22, no. 9, pp. 364-373, 2011.

[52] T.-A. Matsuoka, H. Kaneto, T. Miyatsuka et al., "Regulation of MafA expression in pancreatic $\beta$-cells in $d b / d b$ mice with diabetes," Diabetes, vol. 59, no. 7, pp. 1709-1720, 2010.

[53] J. Quoyer, C. Longuet, C. Broca et al., "GLP-1 mediates antiapoptotic effect by phosphorylating bad through a $\beta$-arrestin 1-mediated ERK1/2 activation in pancreatic $\beta$-cells," The Journal of Biological Chemistry, vol. 285, no. 3, pp. 1989-2002, 2010. 


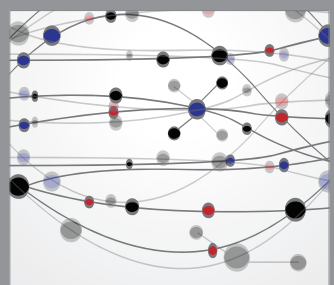

The Scientific World Journal
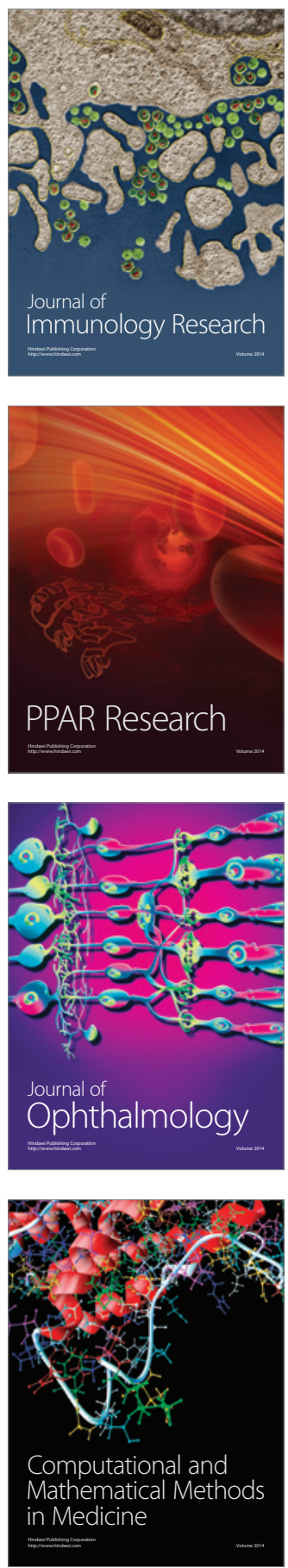

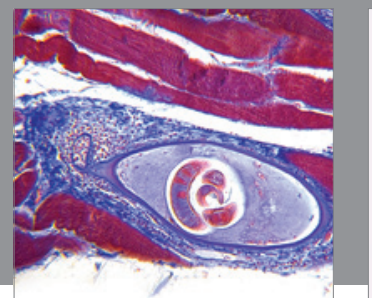

Gastroenterology

Research and Practice
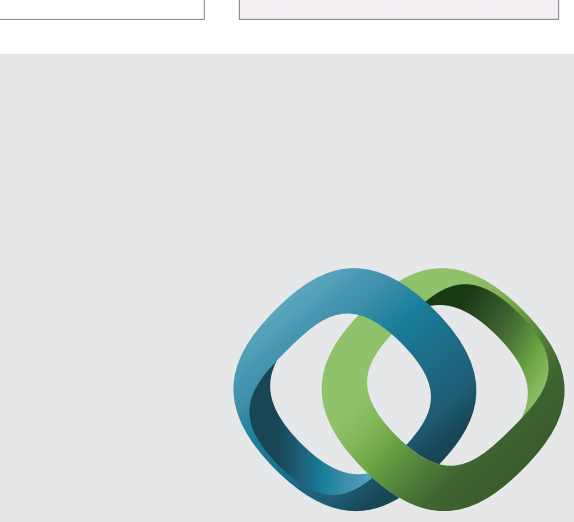

\section{Hindawi}

Submit your manuscripts at

http://www.hindawi.com
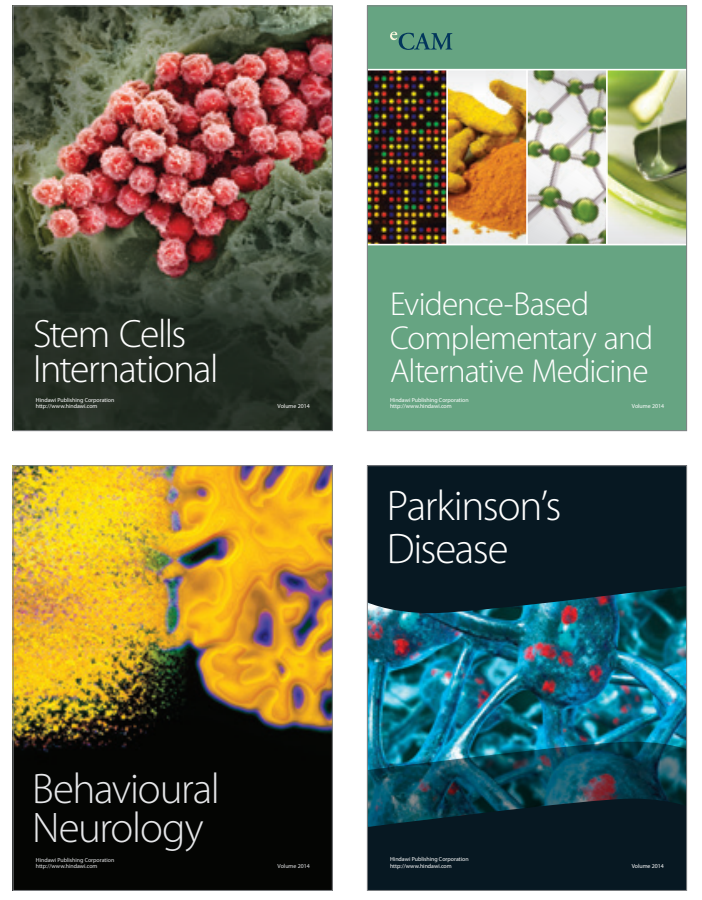
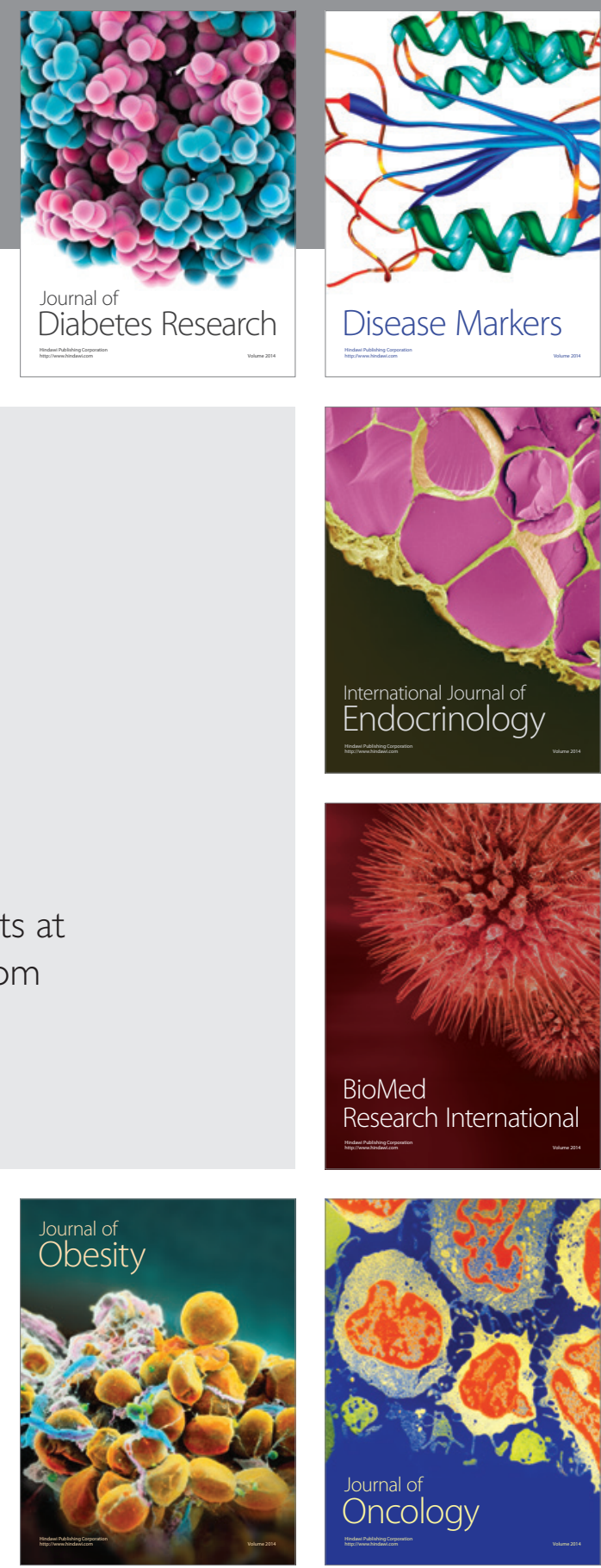

Disease Markers
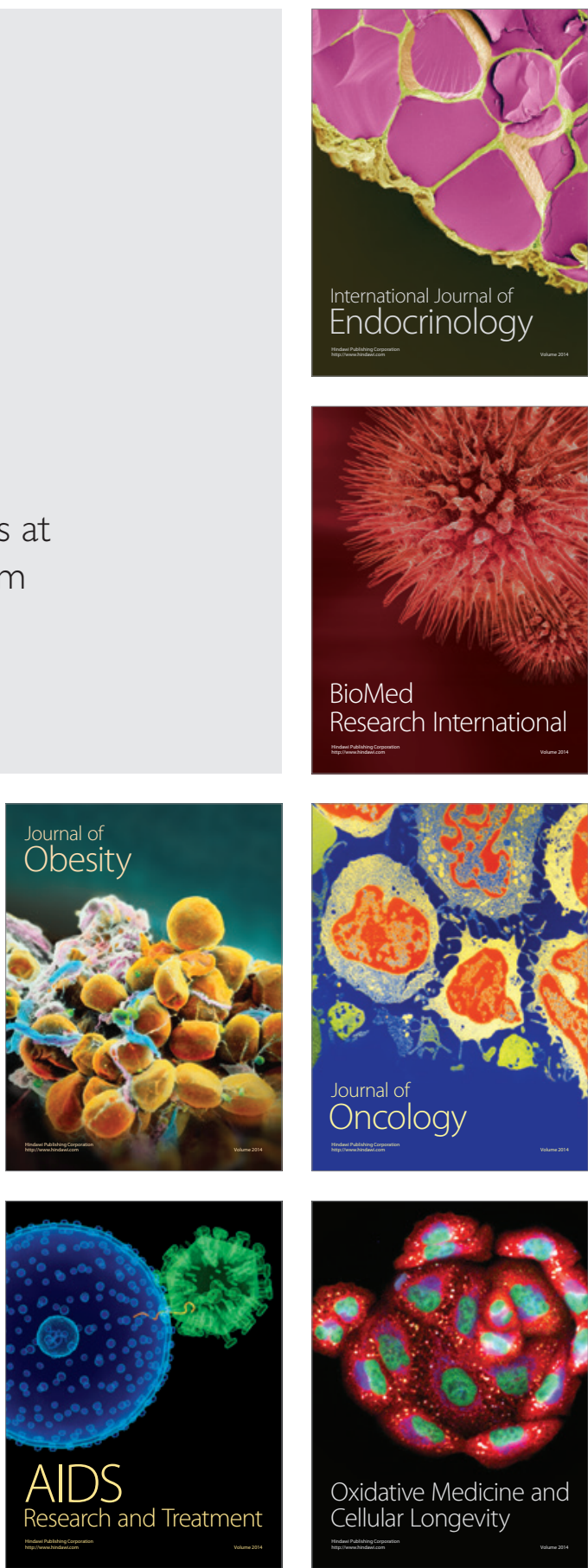